\title{
A New Holistic Conceptual Framework for Leanness Assessment
}

\author{
Cansu Tayaksi \\ Center for Transportation and Logistics, \\ Massachusetts Institute of Technology, Cambridge, USA. \\ E-mail: ctayaksi@mit.edu \\ Muhittin Sagnak \\ Department of Information and Document Management, \\ Izmir Katip Celebi University, Izmir, Turkey. \\ E-mail: muhittin.sagnak@ikcu.edu.tr \\ Yigit Kazancoglu \\ International Logistics Management Department, \\ Yaşar University, Izmir, Turkey. \\ Corresponding author: yigit.kazancoglu@yasar.edu.tr
}

(Received April 4, 2020; Accepted April 12, 2020)

\begin{abstract}
Lean principles, aiming at eliminating waste and increasing efficiency at a company, take their roots from the initiatives of Taiichi Ohno. After the implementation of the principles at the Toyota Motor Company for the first time, businesses started to discover the benefits of lean implementation in terms of efficiency increase. As the adaptation of lean into the manufacturing sector is continuing, the necessity of assessing the level of leanness at the firm-level maintains its importance. Taking systems approach as a basis, the lean performance of an organization should be assessed as a whole. Therefore, we propose a holistic leanness assessment framework, which encapsulates various dimensions of the leanness assessment and we identify the importance and causal relationships between the sub-criteria. In order to identify the importance and causal relationships between the sub-criteria, we used fuzzy Decision Making Trial and Evaluation Laboratory (DEMATEL). Our findings show that the most influencing factor in the cause group is 'technology and product design' which indicates the companies' necessity to focus on Industry 4.0 during their operations. The results also illustrate that the most influenced factor in the effect group is 'productivity', in which companies can investigate strategic competitive advantages. The design of a holistic framework and the implementation of fuzzy DEMATEL offers a way to identify the importance and the causal relationships between the sub-criteria. With the help of a case study conducted in the plastics industry of Turkey, we offer managerial implications that could help managers to implement the proposed structural leanness assessment framework.
\end{abstract}

Keywords- Leanness, Lean manufacturing, Leanness assessment, Fuzzy logic, Fuzzy DEMATEL, Performance assessment.

\section{Introduction}

Lean principles, first implemented at the Toyota Motor Company, were mainly developed by Ohno (1988). The principles used at Toyota and then gained a worldwide reputation due to their success. These principles aim at eliminating waste, thus, increasing efficiency. Lean has many definitions in the literature. According to Schonberger (1987), lean is "the most important productivityenhancing management innovation since the turn of the century." The lean concept works synergistically and aims to create systematic and high-quality processes. Shah and Ward (2003) specified that lean also fulfills customer demand within the required time. Lean is a management philosophy with the goal of supplying the customers the right product at the right place, at the right time, at the right quality and quantity. The implementation phase of lean includes the integration 
International Journal of Mathematical, Engineering and Management Sciences

Vol. 5, No. 4, 567-590, 2020

https://doi.org/10.33889/IJMEMS.2020.5.4.047

of waste elimination and the more efficient production of products that meets customers' needs and expectations (Hines and Taylor, 2000).

Lean concept has been continuously developed and adapted in different sectors of industry, despite initial skepticism among both managers and workers (Womack and Jones, 2003). Today, in the competitive conditions of the market, manufacturing firms face great pressure to meet customer expectations about the quality of the product, as well as providing responsiveness to demand, lower cost and a wide range of product variability. By applying lean principles to the manufacturing sector, firms are able to increase efficiency and fully meet customer expectations.

Although there are several studies with the aim to implement lean manufacturing (Emiliani, 2000; Hines and Taylor, 2000), there is still a lack of systematic measurement of the leanness level of a company. The studies in the literature lack a unifying and holistic measure.

This study aims to contribute to the lack of the any systematic measurement in the literature by (1) Presenting a new holistic leanness assessment framework within a three-level structural format as criteria, subcriteria and measures, (2) Revealing different criteria of lean assessment, such as supplier issues, manufacturing activities, marketing, just-in-time, cost \& financial management, workforce, management responsibility, and quality management under one framework, (3) Using fuzzy DEMATEL method in order to determine the importance level and causal relationships between the sub-criteria and consequently, proposing managerial implications which may guide managers to implement the proposed structural leanness assessment framework. Figure 1 shows the flow diagram identifying the structure of the paper.

Need for an Assessment Structure for Leanness

Literature Review on Leanness Assessment

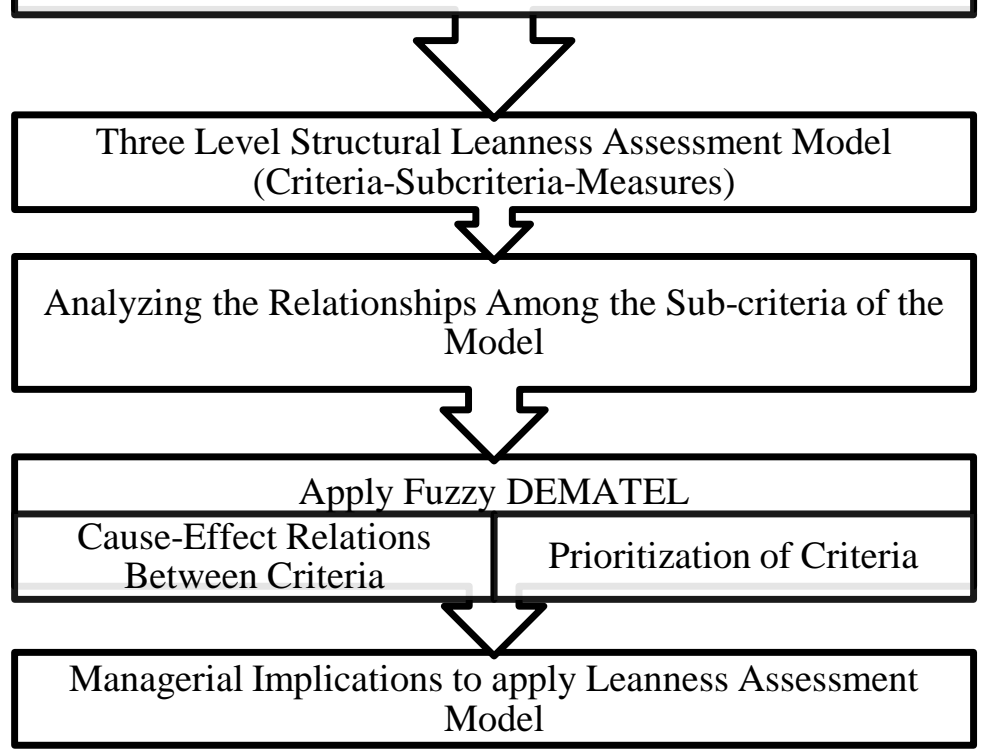

Figure 1. Structure of the paper 
International Journal of Mathematical, Engineering and Management Sciences

Vol. 5, No. 4, 567-590, 2020

https://doi.org/10.33889/IJMEMS.2020.5.4.047

The organization of the rest of the paper is as follows: Section 2 presents a literature review about leanness assessment and the need for a holistic framework. Section 3 and 4 deliver the framework and the methodology of the study respectively and Section 5 presents a case study in the plastics industry and managerial implications. Finally, Section 6 presents the conclusions and future research directions.

\section{Literature Review}

\subsection{Leanness Assessment in the Literature}

The implementation of leanness by companies implies achieving goals and gaining more efficient output with less input (Bayou and de Korvin, 2008). Therefore, being able to measure lean performance is vital for firms; however, there are few studies that contribute to the approaches for measuring leanness from the point of a holistic framework development (Vinodh and Chintha, 2011).

The overall performance of the current or the new systems should be measured and controlled using various performance measures (Deming, 1986; Imai, 1986). The continuous improvement approach suggests that performance measurement is not only for lean organizations but also for any type of organization. Two key aspects are 'leanness is a process, a journey, not an end state' (Liker, 1998) and 'if you can't measure it, you can't manage it' (Shaw and Costanzo, 1970). Therefore, making assessments throughout the firms is vital to identify deficiencies and potential improvements in the lean concept. Some studies focus on the measurement of the management systems' leanness, pointing to a need for a unifying measure of the effects of these practices (Goodson, 2002; Bayou and de Korvin, 2008; Singh et al., 2010). Bhasin (2008) indicates that the firms should understand how the measures of key performance could help an organization to gain strong outcomes in their area, and in parallel, Saurin et al. (2011) point to the significance of practicing lean assessment in the early stages of lean practices.

Although the existing lean assessment methods in the literature with their own strengths and weaknesses, there is no perfect method for measuring the performance (Devlin et al., 1993). Different practices of lean are combined in assessing manufacturing leanness. The practices measure different aspects, including inventory size, quality defects, Kaizen and asset reduction (Emiliani, 2000), as a result, managers need to unify the measurement process of the effects of applying lean, and, it is important that measurement should integrate these practices into one scalar in a meaningful way (Bayou and de Korvin, 2008). According to Bayou and de Korvin (2008), the manufacturing leanness should entail seven characteristics, which are being dynamic, relative, fuzzy logical, objective, long term, integrating and comprehensive.

\subsection{Need for a Holistic Framework}

There are many studies in the literature that suggests for a successful lean implementation process, the lean principles have to be applied as a complete business system (Womack and Jones, 1996; Kennedy and Widener, 2008). All functions and processes of a business act as an incorporated and compatible system by using the lean principles as a way to create better value to customers and eliminate waste. A lean enterprise takes the integration of lean practices across all the operations and the other business functions as a basis (Fullerton et al., 2014).

As systems approach suggests, an organization is composed of interdepending and interacting parts and management should look to the organization as a unity or a system made up of sub-systems. For a successful lean implementation process covered in a holistic view, organizations should apply 
International Journal of Mathematical, Engineering and Management Sciences

Vol. 5, No. 4, 567-590, 2020

https://doi.org/10.33889/IJMEMS.2020.5.4.047

the lean principles into all functions of the organization, including accounting, sales and marketing and human resources (Pakdil and Leonard, 2014). As a result, the assessment of leanness in an organization requires an integrated approach that considers all functional developments regarding the implementation of lean. Some qualitative assessments in the literature focus on employee perception (Feld, 2000; Conner, 2001; Goodson, 2002; Soriano-Meier and Forrester, 2002; Doolen and Hacker, 2005; Shah and Ward, 2007; Fullerton and Wempe, 2009; Bhasin, 2011). Other studies have created quantitative assessments using various performance metrics (Bayou and de Korvin, 2008; Behrouzi and Wong, 2011; Wan and Frank Chen, 2008). The managers are very keen on learning how to use the measures for having more control over the lean implementation process. However, all of the models presented for leanness measurement either focus on quantitative measures or qualitative indicators, and none of those studies have concentrated on creating a perspective which combines both the qualitative and quantitative indicators, despite Azadeh et al. (2015) call for a measurement tool for evaluating the efficiency and effectiveness of the implementation of lean throughout an entire organization. Table 1 exhibits a summary of the studies which presented a lean assessment model. These studies usually focus on different aspects of lean management rather than evaluating it as a whole system.

Table 1. Lean assessment dimensions in literature

\begin{tabular}{|c|c|c|}
\hline Researcher, Year & Enabler/ Criteria & Method \\
\hline Almomani et al. (2014) & $\begin{array}{l}\text { The cost of implementation, Time of completion, Benefit, } \\
\text { Administrative constraints, Technological capabilities, Risk }\end{array}$ & AHP \\
\hline Azadeh et al. (2015) & $\begin{array}{l}\text { Manufacturing leanness } \\
\text { management, Management responsibility, Employees leanness, } \\
\text { Manufacturing leanness strategy, Leanness of technology }\end{array}$ & $\begin{array}{l}\text { Weighted FCM, FDEA, } \\
\text { DEMATEL, AHP, DEA }\end{array}$ \\
\hline Azevedo et al. (2012) & $\begin{array}{l}\text { Supplier Relationships and Long-Term } \\
\text { Business Relationships, Total Quality Management, Customer } \\
\text { Relationships, Just-in-Time, Pull Flow }\end{array}$ & The Delphi Technique \\
\hline Bayou and de & Inventory Management, Cost Manag & Fuzzy Approach \\
\hline Behrouzi & Waste elim & Fuzzy Logic Approach \\
\hline Bhasin (2012) & Finance, Customer, Process, People, Future & Balance Scorecard \\
\hline Doolen and Hacker (2005) & $\begin{array}{l}\text { Manufacturing Equipment and Processes, Shop-Floor Management, } \\
\text { New Product Development, Supplier Relationships, Customer } \\
\text { Relationships, Workforce Management }\end{array}$ & $\begin{array}{l}\text { Development of survey } \\
\text { instrument, Exploratory } \\
\text { study }\end{array}$ \\
\hline Hosseini Nasab et al. (2012) & $\begin{array}{l}\text { Standardized Work, Work Balancing, Work Levelling, Pull } \\
\text { Production, Total Production Maintenance, Zero Defects Quality } \\
\text { Control, Single Minute Exchange of Dies (SMED), Continuous } \\
\text { Improvement, Visual Management, }\end{array}$ & $\begin{array}{l}\text { AHP, ANN, A3 (Adaptive } \\
\text { AHP approach) }\end{array}$ \\
\hline Pakdil and Leonard (2014) & $\begin{array}{l}\text { Process, Time Effectiveness, Human Resources, Delivery, Inventory, } \\
\text { Cost, Customer, Quality }\end{array}$ & Fuzzy Approach \\
\hline Shah and Ward (2007) & $\begin{array}{l}\text { Supplier Feedback, JIT Delivery, Developing Suppliers, Involved } \\
\text { Customers, Pull System, Continuous Flow, Setup Time Reduction, } \\
\text { Total Productive/Preventive Maintenance, Statistical Process } \\
\text { Control, Employee Involvement }\end{array}$ & $\begin{array}{l}\text { Instrument Development, } \\
\text { Exploratory analysis using } \\
\text { EFA, Confirmatory } \\
\text { analysis using CFA }\end{array}$ \\
\hline Singh et al. (2010) & $\begin{array}{l}\text { Suppliers Issues, Lean Practices, Investment Priorities, Customers } \\
\text { Issues, Various Wastes }\end{array}$ & Human Judgement Error \\
\hline Vinodh and Chintha (2011) & $\begin{array}{l}\text { Manufacturing management, Manufacturing strategy, Management } \\
\text { responsibility, Technology, Workforce }\end{array}$ & $\begin{array}{l}\text { Multigrade Fuzzy Logic } \\
\text { Approach }\end{array}$ \\
\hline Wan and Chen (2008) & Total time, Total cost, Value & DEA \\
\hline
\end{tabular}

In this study, we investigated a comprehensive list of measures consisting of both qualitative and quantitative leanness measures, due to the integration of qualitative and quantitative indicators' potential to create more complete and synergistic utilization of data and the lack of this combined 
measurement model in the literature. Also, we aim at providing a new holistic framework for implementing lean, which integrates the different dimensions in an organization, such as supplier issues, manufacturing activities, marketing, just-in-time, cost and financial management, workforce, management responsibility, and quality management. In order to achieve a systematic lean assessment, we propose a framework consists of a three-dimensional hierarchy, which consists of main criteria, sub-criteria, and measures, respectively.

This study is exclusively incorporating all of the eight key areas into one conceptual framework, which includes a three-level structure as criteria, sub-criteria, and measures and performing industry-specific research.

\section{Proposed Framework}

Many studies focus on the necessity to identify relevant measures for lean assessment and discuss the difficulty of measuring and evaluating lean performance (Hervani et al., 2005). Even though there are numerous studies with the aim of lean assessment, they are focusing mostly on specific departments of the businesses. Observing the need for a holistic assessment framework to assess the level of leanness in a company as a whole, we developed a framework that could help businesses with their assessment activities. As the first step for developing our framework, we investigated literature in detail, combined all the studies under one structure, and added the missing criteria/subcriteria for better measurement. See Figure 2 for our threefold framework.

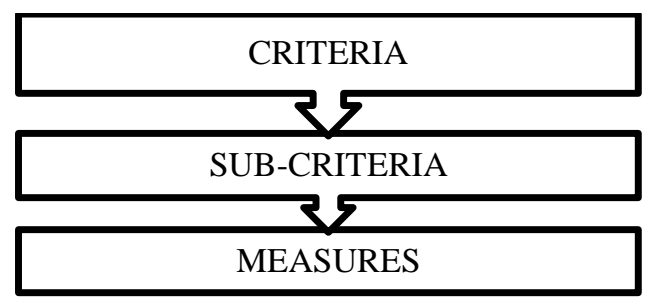

Figure 2. The proposed hierarchy for three-level structure as criteria, sub-criteria, and measures

Our framework contains 8 criteria, which are supplier issues, Manufacturing Activities, Marketing, Just-in-Time, Cost and Financial Management, Workforce, Management Responsibility, and Quality Management. Under this framework, we present 23 sub-criteria and 209 measurements after a comprehensive review of the literature. We assembled the main criteria and sub-criteria of the leanness assessment framework from the related literature regardless these authors have presented a leanness assessment framework or not. Table 2 shows the main criteria and sub-criteria for the proposed lean assessment framework. 
International Journal of Mathematical, Engineering and Management Sciences

Vol. 5, No. 4, 567-590, 2020

https://doi.org/10.33889/IJMEMS.2020.5.4.047

Table 2. Main criteria and sub-criteria for leanness assessment framework

\begin{tabular}{|c|c|}
\hline \multicolumn{2}{|r|}{ SUPPLIER ISSUES } \\
\hline Supplier Relationship Management & $\begin{array}{l}\text { Biazzo and Panizzolo (2000); Shah and Ward (2003); Liker (2004); Bhasin and } \\
\text { Burcher (2006); Pettersen (2009); Jabbour et al. (2013); Pakdil and Leonard } \\
\text { (2014) }\end{array}$ \\
\hline Procurement Management & Our Contribution \\
\hline \multicolumn{2}{|r|}{ MANUFACTURING ACTIVITIES } \\
\hline Product Design & $\begin{array}{l}\text { González-Benito (2005); González-Benito and González-Benito (2005); Jabbour } \\
\text { et al. (2013) }\end{array}$ \\
\hline Layout Design & Our Contribution \\
\hline Production Planning & Vinodh and Chintha (2011); Azadeh et al. (2015) \\
\hline Inventory Management & $\begin{array}{l}\text { Bayou and de Korvin (2008); Searcy (2009); Goodson (2002); Taj (2005); } \\
\text { Pettersen (2009) }\end{array}$ \\
\hline Production Process & Pakdil and Leonard (2014); Liker (2004) \\
\hline Productivity & $\begin{array}{l}\text { Vinodh and Chintha (2011); Azadeh et al. (2015); Allen et al. (2001); Searcy } \\
\text { (2009) }\end{array}$ \\
\hline Technology & Vinodh and Chintha (2011); Azadeh et al. (2015) \\
\hline \multicolumn{2}{|r|}{ MARKETING } \\
\hline Customer Relationship Management & Azevedo et al. (2012) \\
\hline Customer Satisfaction & Chan et al. (2003); Bhasin (2012) \\
\hline Sales management & Our Contribution \\
\hline \multicolumn{2}{|r|}{ JUST-IN-TIME } \\
\hline Adaptation of JIT Philosophy & Liker (2004); Pakdil and Leonard (2014) \\
\hline JIT Implementation & Shah and Ward (2007) \\
\hline \multicolumn{2}{|r|}{ COST AND FINANCIAL MANAGEMENT } \\
\hline Cost Management & $\begin{array}{l}\text { Hayes and Wheelwright (1984); Allen et al. (2001); Doolen and Hacker (2005); } \\
\text { González-Benito (2005); González-Benito and González-Benito (2005); Bayou } \\
\text { and de Korvin (2008); Wan and Frank Chen (2008); Searcy (2009); Vinodh and } \\
\text { Chintha (2011); Behrouzi and Wong (2011); Jabbour et al. (2013); Azadeh et al. } \\
\text { (2015) }\end{array}$ \\
\hline Financial Management & Almomani et al. (2014); Sharma and Bhagwat (2007) \\
\hline \multicolumn{2}{|r|}{ WORKFORCE } \\
\hline Employee Involvement & $\begin{array}{l}\text { Vinodh and Chintha (2011); Azadeh et al. (2015); Pakdil and Leonard (2014); } \\
\text { Liker (2004); Fullerton and Wempe (2009); Goodson (2002); Doolen and Hacker } \\
\text { (2005); Shah and Ward (2007); Taj (2005); Pettersen (2009) }\end{array}$ \\
\hline Employee Cross-functioning & $\begin{array}{l}\text { Biazzo and Panizzolo (2000); Jabbour et al. (2013); Shah and Ward (2003); } \\
\text { Bhasin and Burcher (2006); Soriano-Meier and Forrester (2002); Pettersen (2009) }\end{array}$ \\
\hline Employee Benefits & Almomani et al. (2014) \\
\hline \multicolumn{2}{|r|}{ MANAGEMENT RESPONSIBILITY } \\
\hline Organizational Structure and Management & Vinodh and Chintha (2011); Azadeh et al. (2015) \\
\hline Applying lean practices in management & Our Contribution \\
\hline \multicolumn{2}{|r|}{ QUALITY MANAGEMENT } \\
\hline Value Management & Wan and Frank Chen (2008) \\
\hline Total Quality Management & Doolen and Hacker (2005); Shah and Ward (2007) \\
\hline
\end{tabular}

\subsection{Supplier Issues}

Implementing lean principles in all processes between a buyer and supplier is crucial because when suppliers practice lean processes, they reduce their inventory level and lower the stock out costs. Therefore, the suppliers which adopt lean processes in their internal processes will be more coherent with the buyer's logistics requirements (Wu, 2003). 
International Journal of Mathematical, Engineering and Management Sciences

Vol. 5, No. 4, 567-590, 2020

https://doi.org/10.33889/IJMEMS.2020.5.4.047

Table 3. Sub-criteria and measures for the supplier issues main criterion

\begin{tabular}{l|l}
\hline \multicolumn{2}{c}{ SUPPLIER ISSUES } \\
\hline Having communication and making suggestions to suppliers & $\begin{array}{l}\text { Attempt to reduce the average number of supplier of the most } \\
\text { important parts/ materials } \\
\text { Supplier Related Procedures are written or documented in the IT } \\
\text { applications at the company } \\
\text { Evaluation and decrease in the total supply cost } \\
\text { Establishing a network with the partners who exercise zero } \\
\text { inventory system. }\end{array}$ \\
$\begin{array}{l}\text { Involve suppliers in new product development } \\
\text { Maintaining quality of products sent by suppliers }\end{array}$ & $\begin{array}{l}\text { Eliminate distant suppliers from manufacturer location } \\
\text { Reducing time to supply products }\end{array}$ \\
$\begin{array}{l}\text { Keeping long term partnerships with the most important } \\
\text { suppliers } \\
\text { The extent of the contract with the foremost suppliers } \\
\begin{array}{l}\text { Percentage of parts delivered JIT by the suppliers } \\
\text { Helping supplier development \& increasing their } \\
\text { performance level (technological assistance, financial } \\
\text { assistance, training in quality issues) }\end{array} \\
\begin{array}{l}\text { Lean production tools usage rate by suppliers } \\
\text { Document transmission percentage through EDI (Electronic } \\
\text { Data Interchange) with suppliers }\end{array}\end{array}$ \\
\hline
\end{tabular}

Supplier issues dimension has two sub-dimensions, supplier relationship management, and procurement management. Procurement management is not mentioned in literature as a dimension, sub-dimension or measure; however, some measures in the literature did not fit under the supplier relationship management sub-dimension, so they were collected under a new sub-dimension, called procurement management due to their relevance on the procurement management subject. Table 3 represents the sub-criteria and the measures for the supplier issues main criterion.

\subsection{Manufacturing Activities}

According to Bayou and de Korvin (2008), implementation of leanness strategy into the manufacturing activities is a way to obtain a better output with less input, regarding organizational goals. In their statement, output refers to the quality and quantity of the products for sale, and the ideal customer service level and the input refer to the quantity and the cost of the physical resources used. Narasimhan et al. (2006) also highlighted that waste minimization for the efficient use of an organization's resources is a vital aspect of leanness due to the main aim of lean manufacturing is reducing waste and non-value added activities.

This dimension includes manufacturing related issues as product design, layout design, production planning, inventory management, production process, productivity, and technology. Table 4 represents the sub-criteria and measures for manufacturing activities. 
International Journal of Mathematical, Engineering and Management Sciences

Vol. 5, No. 4, 567-590, 2020

https://doi.org/10.33889/IJMEMS.2020.5.4.047

Table 4. Sub-criteria and measures for the manufacturing activities main criterion

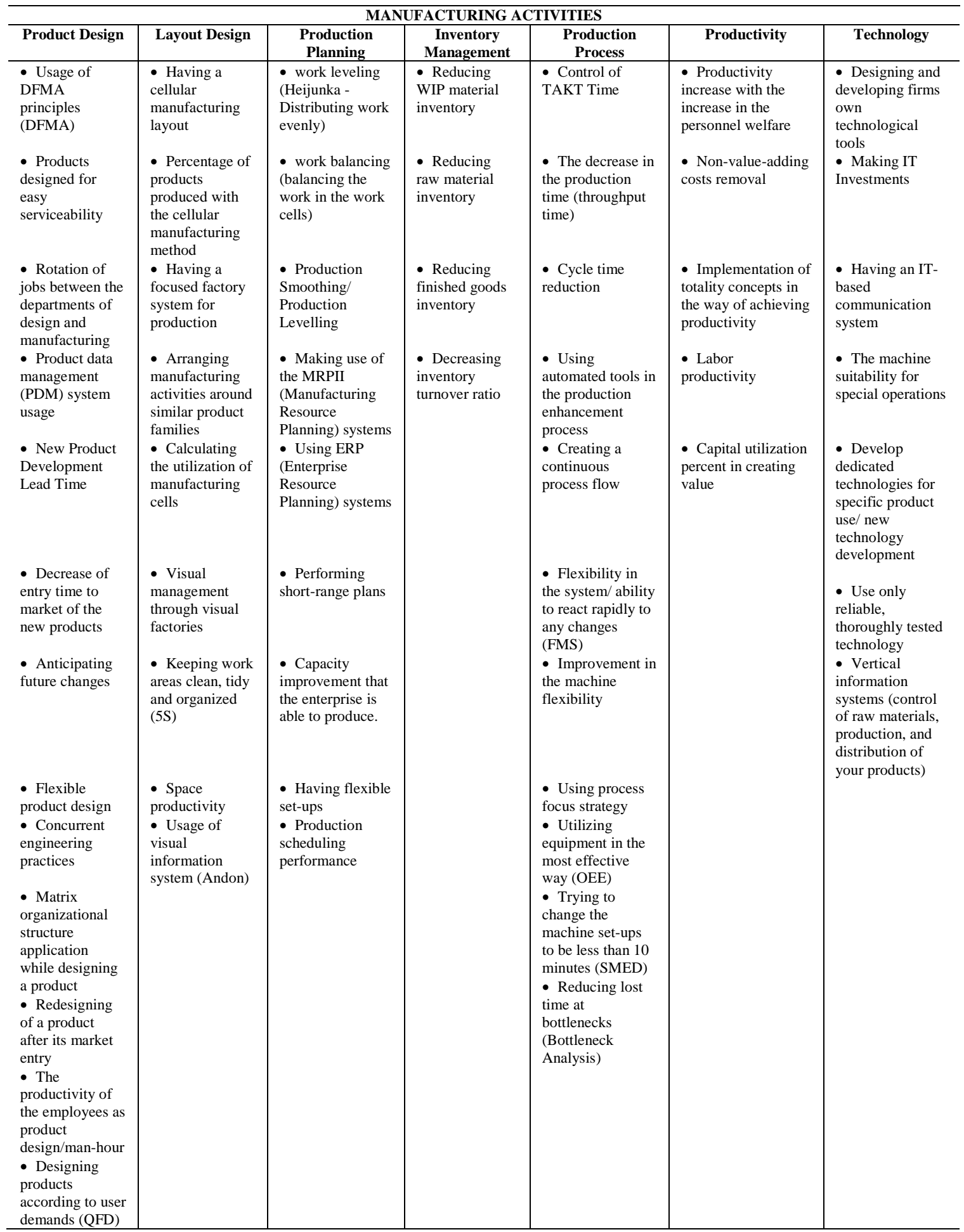


International Journal of Mathematical, Engineering and Management Sciences

Vol. 5, No. 4, 567-590, 2020

https://doi.org/10.33889/IJMEMS.2020.5.4.047

\subsection{Marketing}

Womack and Jones (1996) emphasized that true lean system applications involve the application of all the principles along the value stream, not just in certain defined parts. However, few studies in the literature explore the integration of lean principles in the marketing function. As Piercy and Morgan (1997) stated, great improvements could result from lean thinking in every business function, and in particular, for marketing. The lean thinking concept should be understood by marketing scholars and executives, who should be proactive in using lean thinking to improve the performance of the marketing function.

As mentioned earlier, the lean implementation should be conducted through all functions of an organization according to the systems approach. Therefore, assessment of the lean implementation should include the marketing function as well. Adding the marketing dimension in our conceptual framework we present three sub-dimensions: customer relationship management, customer satisfaction, and sales management. Table 5 represents the sub-criteria and the measures for the marketing main criterion.

Table 5. Sub-criteria and measures for the marketing main criterion

\begin{tabular}{|c|c|c|}
\hline \multicolumn{3}{|c|}{ MARKETING } \\
\hline Customer Relationship Management & Customer Satisfaction & Sales Management \\
\hline $\begin{array}{l}\text { Transparent data sharing with } \\
\text { customers }\end{array}$ & Customer retention rate & $\begin{array}{l}\text { Improvement in the market share } \\
\text { by product group }\end{array}$ \\
\hline $\begin{array}{l}\text { Employee empowerment for solving the } \\
\text { problems of the customers }\end{array}$ & Increase in customer satisfaction index & $\%$ sales from new products \\
\hline $\begin{array}{l}\text { Prevalence of the continuous } \\
\text { improvement culture (regarding } \\
\text { customer response) }\end{array}$ & Products exceeding the customers' expectations & Increase in sales volume \\
\hline $\begin{array}{l}\text { Customers involvement in product } \\
\text { design }\end{array}$ & The decrease in the customer complaint & New market development \\
\hline $\begin{array}{l}\text { Transparent data sharing with } \\
\text { customers }\end{array}$ & $\begin{array}{l}\text { Improvement of the service quality level } \\
\text { (customer-defined) } \\
\text { On-time delivery to the customer } \\
\text { Responsiveness (customer-defined) } \\
\text { After-sale services and satisfaction rate } \\
\text { Increase in the percentage of the resale } \\
\text { The decrease in the return rates } \\
\text { Service centers well equipped with spare parts }\end{array}$ & \\
\hline
\end{tabular}

\subsection{Just-in-Time}

Just-in-Time is a management practice that supports the idea of having the necessary amount of material available where it is needed when it is needed. The main aim is reducing work-in-process inventory and unnecessary delays on flow time (Demeter and Matyusz, 2011; Furlan et al., 2011). Huson and Nanda (1995) argue that in an integration system, lean production should be considered as a multi-dimensional method, including various management practices, and Just-in-Time is described as one of the key principles (Gurumurthy and Kodali, 2009; Demeter and Matyusz, 2011).

In our framework, we divided the Just-in-time dimension into two sub-dimensions. Adaptation of JIT philosophy, the former, concerns adopting the management practices of JIT throughout an organization; JIT implementation, the latter, is the implementation process of JIT after the 
International Journal of Mathematical, Engineering and Management Sciences

Vol. 5, No. 4, 567-590, 2020

https://doi.org/10.33889/IJMEMS.2020.5.4.047

internalizing phase. Table 6 represents the sub-criteria and the measures for the just-in-time main criterion.

Table 6. Sub-criteria and measures for the just-in-time main criterion

\begin{tabular}{|c|c|}
\hline \multicolumn{2}{|c|}{ JUST IN TIME } \\
\hline Adaptation of JIT Philosophy & JIT Implementation \\
\hline $\begin{array}{l}\text { Having the essential amount of material available where it is } \\
\text { needed when it is needed }\end{array}$ & The decrease in unnecessary delays in flow-time \\
\hline Production in small lot sizes & $\begin{array}{l}\text { The decrease in the late delivery rates from suppliers/ JIT } \\
\text { Delivery }\end{array}$ \\
\hline Executing a pull production system & $\begin{array}{l}\text { Delivering the materials just-in-time in a manufacturing } \\
\text { environment with the help of KANBAN }\end{array}$ \\
\hline Percentage of the pull system usage in a year - degree of pull & Process sequence and flow optimization in shop floor \\
\hline $\begin{array}{l}\text { Flexibility in the adjustment of the number of workers } \\
\text { according to demand fluctuation }\end{array}$ & JIT product delivery \\
\hline Having company-wide commitment & $\begin{array}{l}\text { Increase in the right products delivery in yearly base } \\
\text { Increase in the right quantity delivery in yearly base } \\
\text { Increase in the on-time delivery in yearly base } \\
\text { EDI (Electronic Data Interchange) usage rate between customers, } \\
\text { sales and production planning departments } \\
\text { Continuous flow }\end{array}$ \\
\hline
\end{tabular}

\subsection{Cost and Financial Management}

Comm and Mathaisel (2000) described leanness as a management philosophy aimed at reducing cost and cycle time throughout the entire value chain while continuing to develop product performance. Hopp and Spearman (2004) stated that the core of lean production is waste reduction, which will lead to cost-reducing. Emiliani (2000) pointed out, that the customer and stockholder pressure on senior management of a firm for the improvement in the financial position creates awareness about the leanness level of the firm.

For reaching a comprehensive assessment of the leanness level of the firm, we combined cost management and financial management in order to establish a new dimension. Table 7 represents the sub-criteria and the measures for the cost management and financial management main criterion.

Table 7. Sub-criteria and measures for the cost \& financial management main criterion

\begin{tabular}{|c|c|}
\hline \multicolumn{2}{|c|}{ COST \& FINANCIAL MANAGEMENT } \\
\hline Cost Management & Financial Management \\
\hline $\begin{array}{l}\text { Having a costing system with the aim of identifying value-adding } \\
\text { and non-value adding activities }\end{array}$ & Increase in Earnings per share \\
\hline The decrease in Warranty Costs & $\begin{array}{l}\text { Increase in Current ratio - [ current assets - current } \\
\text { liabilities] }\end{array}$ \\
\hline The decrease in service cost & Increase in rate of return on capital employed \\
\hline Amount of investment on lean tools & Increase in Profit \\
\hline The decrease in manufacturing cost & Increase in Capital efficiency \\
\hline The decrease in inventory cost & Increase in the Return on Investment \\
\hline The decrease in COPQ (Cost Of Poor Quality) & Cash flow increase \\
\hline The decrease in raw material Cost & Market share increase \\
\hline The decrease in labor cost & Profits/employee increase \\
\hline Reducing transportation cost through strategic supplier selection & \\
\hline Operating cost for lean tool implementation & \\
\hline Kaizen method of product pricing (cont. cost improvement) & \\
\hline The decrease in scrap rate & \\
\hline The decrease in the logistics cost & \\
\hline
\end{tabular}


International Journal of Mathematical, Engineering and Management Sciences

Vol. 5, No. 4, 567-590, 2020

https://doi.org/10.33889/IJMEMS.2020.5.4.047

\subsection{Workforce}

Worker involvement and expansion of their responsibilities and giving them autonomy is vital for continuous quality improvement programs. In implementing lean, beneficial processes include employee recruitment and selection, educating and training, evaluating and rewarding their contributions to the process and increasing their empowerment and responsibility.

The workforce dimension consists of the three sub-dimensions which related to the employeerelated processes. They are employee involvement, employee cross-functioning, and employee benefits. Table 8 represents the sub-criteria and the measures for the workforce main criterion.

Table 8. Sub-criteria and measures for the workforce main criterion

\begin{tabular}{|c|c|c|}
\hline \multicolumn{3}{|c|}{ WORKFORCE } \\
\hline Employee Involvement & Employee Cross-Functioning & Employee Benefits \\
\hline Standardized Work for employees & Multi-skilled personnel/ personnel flexibility & $\begin{array}{l}\text { Healthier workforce, decrease in } \\
\text { illness }\end{array}$ \\
\hline $\begin{array}{l}\text { Employee's willingness to adapt } \\
\text { changes }\end{array}$ & Multifunctional workers rate & $\begin{array}{l}\text { Healthier workforce, decrease in } \\
\text { injury due to accidents }\end{array}$ \\
\hline $\begin{array}{l}\text { workforce ability to be flexible, to } \\
\text { adapt and to use new technologies }\end{array}$ & Implementation of a job rotation system & Safety improvement \\
\hline Employee empowerment & $\begin{array}{l}\text { Pilot training program for the appreciation of } \\
\text { lean practices }\end{array}$ & $\begin{array}{l}\text { Labor Turnover (for measuring health } \\
\text { and safety per employee) }\end{array}$ \\
\hline $\begin{array}{l}\text { Teamwork for effective } \\
\text { implementation of lean practices }\end{array}$ & Cross-training of employees & $\begin{array}{l}\text { Absenteeism (for measuring health } \\
\text { and safety per employee) }\end{array}$ \\
\hline $\begin{array}{l}\text { Worker's ability to identify defective } \\
\text { parts and power to stop the line }\end{array}$ & Workforce development & Employee Morale \\
\hline Job rotation rate & Quality of professional/technical development & $\begin{array}{l}\text { Performance assessment and its } \\
\text { projection on salaries }\end{array}$ \\
\hline Employee Commitment & Quality of leadership development & \\
\hline Retention of top employees & Employee perception surveys & \\
\hline $\begin{array}{l}\text { Expansion of autonomy and } \\
\text { responsibility }\end{array}$ & $\begin{array}{l}\text { The employee's ability to conduct the assigned } \\
\text { tasks }\end{array}$ & \\
\hline Kaizen circles & Hiring expert employees & \\
\hline Worker training rate & & \\
\hline $\begin{array}{l}\text { Number of suggestions in a year } \\
\text { which made by employees }\end{array}$ & & \\
\hline The implementation rate of the & & \\
\hline
\end{tabular}

\subsection{Management Responsibility}

A radical rethinking over how the management of a firm uses the lean principles and methods is essential for reaching optimal performance level throughout an enterprise. While an organization is at the adaption stage, they focus more on the 'process-centered approach', such as the elimination of waste and reduction of cost. As the stage on to the adaptation phase, the focus should be more on the human-centered approach through empowerment and management of the human resources in the work design (Wong et al., 2014).

Management responsibility dimension consists of two sub-dimensions: Organizational Culture and Management, and Applying lean practices in management. Table 9 represents the sub-criteria and the measures for the management responsibility main criterion. 
International Journal of Mathematical, Engineering and Management Sciences

Vol. 5, No. 4, 567-590, 2020

https://doi.org/10.33889/IJMEMS.2020.5.4.047

Table 9. Sub-criteria and measures for the management responsibility main criterion

\begin{tabular}{|c|c|}
\hline \multicolumn{2}{|c|}{ MANAGEMENT RESPONSIBILITY } \\
\hline Organizational Structure and Management & Applying Lean Practices in Management \\
\hline Smooth information flow & Application of waste elimination (Muda) \\
\hline Interchange-ability of personnel & Continuous improvement (Kaizen) \\
\hline Integrated Functions & A pilot study for new production or business processes \\
\hline Team management for decision making by consensus & Time Management \\
\hline Becoming a learning organization (Hansei) & $\begin{array}{l}\text { Using an organized framework that can be used for strategic } \\
\text { management purposes. (Hoshin Kanri) }\end{array}$ \\
\hline Clear managerial goals & Constant evaluation of management practices (PDCA) \\
\hline Involved management/ Leadership for lean implementation & $\begin{array}{l}\text { Selecting operationalizable, measurable, amenable to evaluation, } \\
\text { and time-bounded targets (SMART) }\end{array}$ \\
\hline Transparency in information sharing & $\begin{array}{l}\text { Visits from management to workplace and observing the practices } \\
\text { followed (Gemba) }\end{array}$ \\
\hline $\begin{array}{l}\text { Management's attention towards investment in FMS } \\
\text { concepts }\end{array}$ & Finding the root causes of the problems \\
\hline Management commitment or adopting lean & \\
\hline Depth and quality of strategic planning & \\
\hline Creating competitive benchmarks & \\
\hline Go and see the problem (Genchi Genbutsu) & \\
\hline
\end{tabular}

\subsection{Quality Management}

Brown et al. (2001) indicate that lean manufacturing enables manufacturing with less input, at a lower cost with less development time, and higher quality levels. Producing with a higher quality level brings the usage of the Total Quality Management process, which, according to Demeter and Matyusz (2011) aims at continuous improvement and sustaining the quality of the product and processes. The actions of TQM include the usage of Six Sigma, quality circles, statistical process control, equipment problem solving and poka-yoke. Wan and Frank Chen (2008) also point that there are various tools and techniques developed to solve specific problems in order to eliminate non-value-added activities, and that process will help becoming lean.

The last dimension is comprised of the sub-dimensions of total quality management and value management. Table 10 represents the sub-criteria and the measures for the quality management main criterion.

Table 10. Sub-criteria and measures for the quality management main criterion

\begin{tabular}{|c|c|}
\hline \multicolumn{2}{|c|}{ QUALITY MANAGEMENT } \\
\hline Value Management & Total Quality Management \\
\hline Value identification through value stream mapping & Quality rating and certification \\
\hline Non-value-adding cost decrease & $\begin{array}{l}\text { Quality of new product development and project management } \\
\text { processes }\end{array}$ \\
\hline Non-value-adding time decrease & Build a culture to stop right away to fix the problems \\
\hline Seven deadly wastes identification & Total productive maintenance \\
\hline Percentage of waste Elimination & Having organization-wide efforts to deliver high-quality products \\
\hline & Usage of TQM tools \\
\hline & Training the supplier personnel in related quality issues \\
\hline & Zero Defects Quality Control \\
\hline & Improvement of the $\mathrm{Cp}$ and $\mathrm{Cpk}$ values of the processes \\
\hline & Usage of statistical process control (SPC) \\
\hline & Reduce in effects of critical products/components \\
\hline & Making surveys to ensure the quality status \\
\hline & Forming quality circles \\
\hline & Poka-yoke / Mistake-Proofing for production \\
\hline & Reducing defects with the usage of autonomation (Jidoka) \\
\hline
\end{tabular}


International Journal of Mathematical, Engineering and Management Sciences

Vol. 5, No. 4, 567-590, 2020

https://doi.org/10.33889/IJMEMS.2020.5.4.047

\section{Methodology}

We used the Decision Making Trial and Evaluation Laboratory (DEMATEL) method to assess the cause-effect relationships between the relevant criteria, and allow an analysis of a structured model. DEMATEL method initiated first at the Battelle Memorial Institute (Gabus and Fontela, 1972; Gabus and Fontela, 1973). The method consists of matrices and digraphs in order to categorize the relevant factors as cause factor, or effect factor, and identify the dependencies between the factors. The pairwise comparisons between the relevant criteria are used to represent the mathematical relationships (Wu and Lee, 2007).

There is a set of factors $C=\left\{C_{1}, C_{2}, \ldots, C_{n}\right\}$, in the DEMATEL method. The pairwise comparisons between the relevant criteria are used to represent the mathematical relationships. Due to the subjectivity and vagueness, in pairwise comparisons, the linguistic terms are used to show the degree of effect of each criterion over others. Table 11 shows these linguistic terms described in positive triangular fuzzy numbers $\left(l_{i j}, m_{i j}, r_{i j}\right)$.

Table 11. Fuzzy linguistic scale

\begin{tabular}{ll}
\hline Linguistic terms & Triangular fuzzy numbers \\
\hline Very high influence (VH) & $(0.75,1.0,1.0)$ \\
High influence (H) & $(0.5,0.75,1.0)$ \\
Low influence (L) & $(0.25,0.5,0.75)$ \\
Very low influence (VL) & $(0,0.25,0.5)$ \\
No influence (No) & $(0,0,0.25)$ \\
\hline
\end{tabular}

The linguistic terms are transferred into fuzzy numbers. Then, the average of pairwise comparisons are defuzzified into crisp values by Converting Fuzzy Data into Crisp Scores (CFCS), which was proposed by Opricovic and Tzeng (2003).

After the defuzzification process, we followed the following step-by-step application:

Step 1: The average of pairwise comparisons constitute $n x n$ direct relation matrix, Z. $Z_{i j}$ represents the degree of the influence of $i^{\text {th }}$ factor to $j^{\text {th }}$ factor, i.e. $Z=\left[Z_{i j}\right]_{n \times n}$.

Step 2: Using formulas (1) and (2), we found the normalized direct relation matrix, $X$, i.e., $X=$ $\left[X_{i j}\right]_{n \times n}$, and $0 \leq X_{i j} \leq 1$.

$X=s \cdot Z$

$s=\frac{1}{\max _{1 \leq i \leq n} \sum_{j=1}^{n} z_{i j}}, \quad i, j=1,2, \ldots, n$

Step 3: Using formula (3), we calculated total relation matrix, T. "I" symbolizes here the identity matrix.

$T=X(I-X)^{-1}$ 
International Journal of Mathematical, Engineering and Management Sciences

Vol. 5, No. 4, 567-590, 2020

https://doi.org/10.33889/IJMEMS.2020.5.4.047

Step 4: Using formulas (4)-(6), we found the sum of values in rows and columns of the total relation matrix, $\mathrm{T}$, and symbolized by $\mathrm{D}$, and $\mathrm{R}$, respectively.

$T=t_{i j}, \quad i, j=1,2, \ldots, n$

$D=\sum_{j=1}^{n} t_{i j}$

$R=\sum_{i=1}^{n} t_{i j}$

Step 5: We drew the cause-effect diagram by graphing the dataset. (D+R), and (D-R) values show the values in the horizontal axis, and in the vertical axis, respectively. $(D+R)$ is called "Prominence", which refers to the level of importance, and $(D-R)$ is called "Relation", which categorizes the factors as cause factor, or effect factor, respectively. If the value of $(D-R)$ is positive, the factor is named as cause factor, and if negative, as effect factor (Wu and Lee, 2007).

\section{Case Study and Managerial Implications}

After the development of our framework, we conducted an application in 18 companies in the plastics industry in Izmir, Turkey. We selected the plastic industry due to its importance for the Turkish economy. According to the data of Turkish Statistical Institute (TUIK), the plastic industry in Turkey generates $4.8 \%$ of the Turkish manufacturing industry in economic terms and mobilizes a labor force rate of $4.2 \%$ within the manufacturing industry labor force. The plastic industry is the $11^{\text {th }}$ biggest industry in Turkey representing nearly 5 billion euros of turnover. Also, the share of plastic industry among the whole manufacturing industry is increasing every year. The export rate of the plastic industry is $4.6 \%$ of Turkish manufacturing industry, and it is also developing (Karaca, 2011).

34 experts carried out pairwise comparisons from these 18 companies, including the general managers, the plant managers, and the production managers. We sent the survey questions, in other words, the matrix for getting the judgments of the experts, by e-mail to the 126 representatives of the plastic industry, and 34 of them replied. We limited the scope of the study to the plastics sector in order to prevent the potential ambiguity that may arise when the analysis is conducted in multiple sectors.

Hervani et al. (2005) pointed out the fact that since the application and the scales are specific to the organizations, there is no generally applicable tool or approach for generalizing the results. Consistent with this, the proposed framework including 8 criteria, 23 sub-criteria, and 209 measurements may be generalized and used in different applications. However, each application is specific to the company, which means, the results may be different when applied in another company.

Table 12 shows the direct relation matrix; Z. We found direct relation matrix by using the formulas (7)-(14) (See Table 13 for the normalized direct relation matrix, X). Following, we calculated normalized direct relation matrix by the formulas (1) and (2). (See Table 14 for the total relation matrix, T). Lastly, we found the total relation matrix by the formula (3) and we calculated D and R 
values by using the formulas (4)-(6). According to the results, a cause-effect diagram occurs as seen in Figure 3.

Using formulas (4)-(6), row totals (D), and column totals (R) of Total Relation Matrix were found, respectively. The dataset is graphed in order to generate a cause-effect diagram. Horizontal axis shows $(D+R)$ values, which refer to the importance level. The vertical axis represents $(D-R)$ values, which classifies each criterion as either cause or effect group. If the value of $(D-R)$ is positive, then the factor is referred to as cause factor, and if negative, as effect factor (Wu and Lee, 2007).

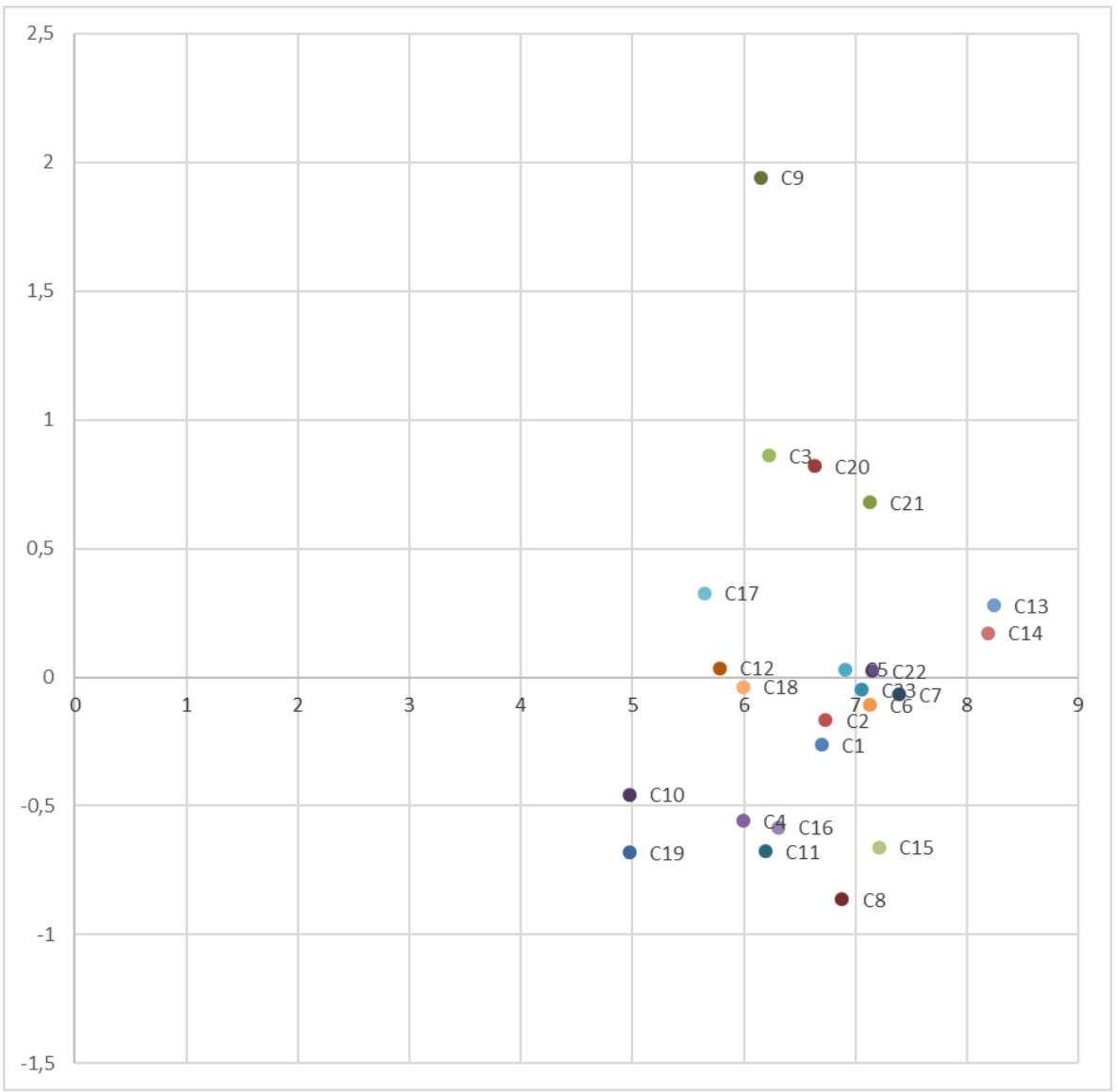

Figure 3. The cause - effect diagram 
International Journal of Mathematical, Engineering and Management Sciences

Vol. 5, No. 4, 567-590, 2020

https://doi.org/10.33889/IJMEMS.2020.5.4.047

Table 12. Direct relation matrix, Z

\begin{tabular}{|c|c|c|c|c|c|c|c|c|c|c|c|c|c|c|c|c|c|c|c|c|c|c|c|}
\hline$N$ & $\vec{U}$ & $\tilde{\delta}$ & 8 & J & 8 & 8 & $\hat{U}$ & $\overbrace{}^{\infty}$ & 8 & Uे & $\bar{\sigma}$ & Uี & $\vec{U}$ & $\stackrel{\vec{U}}{\mathrm{U}}$ & $\tilde{v}$ & $\stackrel{\circlearrowright}{U}$ & $\bar{U}$ & $\stackrel{\infty}{U}$ & $\overrightarrow{\mathrm{U}}$ & ठี & $\overrightarrow{\tilde{U}}$ & $\tilde{\delta}$ & $\tilde{\delta}$ \\
\hline $\bar{U}$ & 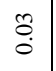 & $\hat{\grave{o}}$ & S. & ?̊. & $\stackrel{\hat{o}}{0}$ & 足 & $\overbrace{0}^{\infty}$ & œ & ֻ) & $\hat{\imath}$ & & $\stackrel{\overbrace{}}{0}$ & $\stackrel{\overbrace{}}{0}$ & هి & : & $\underset{\substack{\infty \\
0}}{0}$ & $\stackrel{n}{0}$ & $\stackrel{8}{0}$ & $\stackrel{8}{0}$ & $\stackrel{8}{0}$ & 3 & $\begin{array}{l}* \\
0\end{array}$ & $\hat{o}$ \\
\hline ¿ & $\begin{array}{l}\infty \\
\infty \\
0\end{array}$ & $\stackrel{8}{\circ}$ & సิ & ?口. & ì & જે & : & $\stackrel{\overbrace{}}{0}$ & $\cong$ & જે & $a$ & 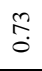 & 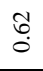 & જે & $\begin{array}{l}\text { f. } \\
0\end{array}$ & 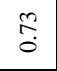 & $\tilde{o}$ & $\stackrel{8}{\circ}$ & $\stackrel{8}{\circ}$ & $\frac{n}{0}$ & $\begin{array}{l}0 \\
: \\
0\end{array}$ & 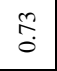 & $\stackrel{\text { }}{\circ}$ \\
\hline$\tilde{\mathcal{U}}$ & $\begin{array}{l}\hat{\imath} \\
\hat{0}\end{array}$ & $\begin{array}{l}\text { S. } \\
0\end{array}$ & $\stackrel{8}{\circ}$ & $\begin{array}{l}n \\
\infty \\
0 \\
0\end{array}$ & $\bar{a}$ & $\stackrel{\overbrace{}}{0}$ & $\bar{a}$ & : & సิ & n̊. & $\curvearrowright$ & ?̊. & i & S. & $\stackrel{\hat{\imath}}{0}$ & 寺 & $\stackrel{n}{0}$ & 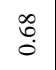 & 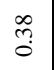 & $\stackrel{m}{\tilde{O}}$ & $\begin{array}{l}\tilde{\sigma} \\
0\end{array}$ & $\begin{array}{l}n \\
n \\
0\end{array}$ & ర్ర \\
\hline さ & స̃ & त̄ & $\stackrel{8}{\circ}$ & $\stackrel{0}{\circ}$ & $\stackrel{\overbrace{}}{0}$ & $\stackrel{\leftrightarrow}{\circ}$ & $\begin{array}{l}1 \\
\infty \\
0 \\
0\end{array}$ & $\begin{array}{l}\swarrow 0 \\
\infty \\
0\end{array}$ & તิ & $\stackrel{n}{0}$ & oे & $\stackrel{\circ}{\circ}$ & $\stackrel{m}{0}$ & ¿̊. & $\begin{array}{c}\infty \\
0 \\
0\end{array}$ & ત̇ & $\begin{array}{l}0 \\
\vdots \\
0\end{array}$ & $\begin{array}{l}\tilde{O} \\
0\end{array}$ & $\begin{array}{l}0 \\
: \\
0\end{array}$ & $\stackrel{\infty}{0}$ & $\begin{array}{l}0 \\
\vdots \\
0\end{array}$ & $\stackrel{0}{0}$ & $\stackrel{n}{n}$ \\
\hline 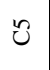 & $\hat{\hat{o}}$ & $\stackrel{\infty}{\infty}$ & : & $\hat{\hat{o}}$ & $\stackrel{\circ}{\circ}$ & $\begin{array}{l}\infty \\
\infty \\
\infty \\
0\end{array}$ & $\begin{array}{l}n \\
\infty \\
0 \\
0\end{array}$ & $\begin{array}{l}\infty \\
\infty \\
\infty \\
0\end{array}$ & స్ & $\stackrel{f}{0}$ & 0 & $\stackrel{f}{0}$ & $\hat{\overbrace{}}$ & $\stackrel{\hat{\sigma}}{0}$ & $\begin{array}{l}0 \\
: \\
o \\
o\end{array}$ & $\stackrel{+}{+}$ & $\stackrel{\infty}{0}$ & 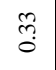 & $\stackrel{\leftrightarrow}{0}$ & $\stackrel{m}{0}$ & 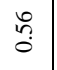 & $\begin{array}{l}0 \\
: \\
0\end{array}$ & : \\
\hline 8 & $\overrightarrow{\dot{o}}$ & $\bar{\sigma}$ & f & $\begin{array}{l}n \\
\infty \\
0 \\
0\end{array}$ & : & $\stackrel{8}{\circ}$ & $\stackrel{\infty}{\sim}$ & $\stackrel{\overbrace{}}{0}$ & స్ & 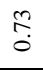 & $\stackrel{\infty}{\circ}$ & 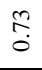 & $\curvearrowright$ & $\hat{\delta}$ & : & $\stackrel{\infty}{0}$ & $\stackrel{n}{0}$ & $\stackrel{\infty}{0}$ & હે & తి & 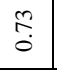 & $\stackrel{0}{0}$ & : \\
\hline$\hat{0}$ & $\begin{array}{l}\text { J } \\
0\end{array}$ & !n & f & $\begin{array}{l}\infty \\
\infty \\
\infty\end{array}$ & $\stackrel{\infty}{\circ}$ & જે & $\stackrel{0}{0}$ & $\bar{\delta}$ & సิ & $\overrightarrow{ }$ & తి & $\vec{\jmath}$ & $\hat{\imath}$ & $\bar{\delta}$ & $\begin{array}{l}\infty \\
\infty \\
\infty\end{array}$ & $\stackrel{S}{\circ}$ & $\stackrel{尺}{0}$ & $\stackrel{\infty}{0}$ & $\underset{0}{\tilde{0}}$ & $\begin{array}{l}n \\
0 \\
0\end{array}$ & $\stackrel{尺}{0}$ & $\stackrel{\overbrace{}}{0}$ & $\hat{o}$ \\
\hline$\stackrel{\infty}{0}$ & 守 & 者 & ডิ & $\overbrace{0}^{\infty}$ & $\stackrel{\infty}{0}$ & $\stackrel{\hat{o}}{0}$ & f & $\stackrel{\leftrightarrow}{0}$ & $\stackrel{2}{0}$ & J & $\infty$ & 守 & in & : & $\stackrel{\hat{0}}{0}$ & $\stackrel{S}{0}$ & $\vec{\jmath}$ & $\stackrel{\circlearrowleft}{0}$ & $\stackrel{S}{0}$ & $\begin{array}{l}0 \\
: \\
0\end{array}$ & $\begin{array}{l}\tilde{O} \\
0\end{array}$ & $\stackrel{\overbrace{}}{0}$ & S. \\
\hline 8 & $\begin{array}{l}0 \\
: \\
0\end{array}$ & $\stackrel{\infty}{0}$ & $\begin{array}{l}\infty \\
\infty \\
0\end{array}$ & $\begin{array}{l}n \\
\infty \\
0 \\
0\end{array}$ & $\stackrel{\overbrace{}}{0}$ & જે & ?. & $\begin{array}{l}\infty \\
\infty \\
\infty \\
\infty\end{array}$ & $\stackrel{\circ}{\circ}$ & ஜ̊ & $i$ & જે & 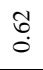 & જે & $\stackrel{\text { }}{\stackrel{0}{0}}$ & 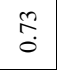 & 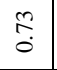 & $\hat{\imath}$ & $\begin{array}{l}\text { : } \\
0 \\
0\end{array}$ & $\stackrel{\infty}{0}$ & $\begin{array}{l}0 \\
n \\
0\end{array}$ & $\underset{0}{0}$ & $\stackrel{\leftrightarrow}{0}$ \\
\hline$\stackrel{\circ}{0}$ & $\begin{array}{l}\infty \\
\stackrel{0}{0} \\
0\end{array}$ & $\hat{\imath}$ & $\stackrel{8}{\circ}$ & $\frac{n}{0}$ & $\stackrel{8}{\circ}$ & $\stackrel{n}{0}$ & : & $\stackrel{n}{0}$ & $\stackrel{\overbrace{}}{\circ}$ & $\stackrel{\text { o̊ }}{\circ}$ & $\bar{\delta}$ & $\begin{array}{l}\infty \\
\infty \\
0 \\
0\end{array}$ & :̊n & तु & \begin{tabular}{l}
\multirow{2}{*}{} \\
$\stackrel{0}{0}$
\end{tabular} & 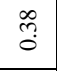 & ले & $\overrightarrow{\tilde{\sigma}}$ & $\bar{~}$ & $\underset{0}{\infty}$ & $\begin{array}{l}0 \\
0 \\
0\end{array}$ & 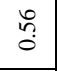 & $\begin{array}{l}0 \\
\vdots \\
\end{array}$ \\
\hline $\bar{u}$ & $\begin{array}{l}\infty \\
\infty \\
0\end{array}$ & $\stackrel{S}{\circ}$ & $\begin{array}{l}\infty \\
\infty \\
0\end{array}$ & సิ & $\stackrel{\infty}{\sim}$ & 총 & 尺 & ถి & 8 & $\stackrel{\overbrace{}}{0}$ & 8 & $\begin{array}{l}\infty \\
\infty \\
0\end{array}$ & $\infty$ & तิ & ถి & 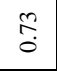 & $\overrightarrow{\widetilde{O}}$ & $\stackrel{\infty}{0}$ & હે & ?̊ & 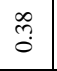 & $\stackrel{\infty}{0}$ & $\overline{\check{~}}$ \\
\hline ปี & $\begin{array}{l}\infty \\
\infty \\
0\end{array}$ & 守 & 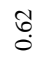 & ஸे & :̊n & $\stackrel{\overbrace{}}{\circ}$ & $\stackrel{\circ}{n}$ & సิ & $\stackrel{\infty}{\substack{0 \\
0}}$ & $\stackrel{\Re}{\circ}$ & જે & $\stackrel{\circ}{\circ}$ & ஜ̊ & $\stackrel{\infty}{0}$ & $\stackrel{f}{*}$ & $\begin{array}{l}\infty \\
\infty \\
0\end{array}$ & $\grave{o}$ & $\overbrace{0}^{\infty}$ & లై & $\stackrel{\Re}{\stackrel{0}{0}}$ & $\begin{array}{l}0 \\
\vdots \\
0\end{array}$ & $\overrightarrow{\tilde{O}}$ & $\stackrel{8}{\circ}$ \\
\hline$\stackrel{m}{U}$ & $\hat{\hat{o}}$ & $\bar{\sigma}$ & $\underset{\delta}{f}$ & 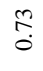 & 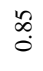 & $\bar{a}$ & $\infty_{\infty}^{\infty}$ & $\stackrel{\hat{o}}{\hat{o}}$ & ర్ర & S. & ठั & S. & $\stackrel{8}{\circ}$ & $\bar{\delta}$ & 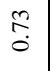 & ?̊ & $\begin{array}{l}\infty \\
\infty \\
\infty\end{array}$ & $\stackrel{\hat{o}}{\hat{o}}$ & $\stackrel{\hat{\theta}}{\hat{\theta}}$ & $\stackrel{S}{0}$ & $\begin{array}{l}0 \\
\stackrel{0}{0} \\
0\end{array}$ & $\hat{\jmath}$ & $\stackrel{\leftrightarrow}{\circ}$ \\
\hline$\vec{U}$ & $\vec{\delta}$ & $\stackrel{\infty}{\infty}$ & : & $\hat{\overbrace{}}$ & $\stackrel{\infty}{\infty}$ & $\bar{\delta}$ & $\infty$ & $\stackrel{\infty}{\infty}$ & $\widetilde{\sigma}$ & : & ठั. & ?̊. & $0^{\circ}$ & $\stackrel{0}{0}$ & $\stackrel{\overbrace{}}{0}$ & $\stackrel{S}{\circ}$ & : & $\stackrel{\hat{\imath}}{0}$ & $\stackrel{尺}{0}$ & 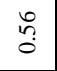 & $\begin{array}{l}0 \\
: \\
0 \\
0\end{array}$ & $\stackrel{\overbrace{}}{0}$ & $\hat{o}$ \\
\hline$\stackrel{n}{u}$ & $\begin{array}{l}\tilde{0} \\
0\end{array}$ & $\stackrel{\infty}{0}$ & $\stackrel{\delta}{\circ}$ & $\stackrel{\infty}{\infty}$ & in & $\stackrel{\overbrace{}}{\circ}$ & $\stackrel{0}{0}$ & $\stackrel{\leftrightarrow}{\circ}$ & $\stackrel{\overbrace{}}{0}$ & ले & 0 & $\circ$ & 0 & $\circ$ & $\stackrel{8}{\circ}$ & $\hat{\hat{o}}$ & $\frac{n}{0}$ & $\stackrel{J}{*}$ & $\begin{array}{l}0 \\
\vdots \\
0\end{array}$ & $\begin{array}{l}0 \\
0 \\
0\end{array}$ & $\begin{array}{l}\text { J } \\
0\end{array}$ & $\begin{array}{l}0 \\
0 \\
0\end{array}$ & $\stackrel{n}{n}$ \\
\hline$\stackrel{\circ}{U}$ & $\begin{array}{l}\infty \\
\stackrel{0}{0} \\
0\end{array}$ & 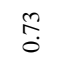 & : & $\begin{array}{l}\text { : } \\
\text { ?n }\end{array}$ & $\stackrel{\infty}{\infty}$ & సิ & $\stackrel{\infty}{\infty}$ & $\stackrel{2}{\circ}$ & ర్రా & ิㅗㅇ & 0 & ర్రా & $0^{\circ}$ & S. & $\begin{array}{l}\infty \\
\infty \\
0 \\
0\end{array}$ & $\stackrel{\leftrightarrow}{\circ}$ & $\stackrel{n}{0}$ & $\stackrel{\infty}{\overbrace{0}^{\infty}}$ & $\begin{array}{l}0 \\
: ? \\
0\end{array}$ & ?̊: & $\begin{array}{l}0 \\
: ? \\
0\end{array}$ & $\stackrel{+}{*}$ & $\stackrel{\infty}{0}$ \\
\hline$\Xi$ & $\overrightarrow{\vec{O}}$ & $\stackrel{\infty}{0}$ & ন্ড & ֻे & : & $\stackrel{8}{\circ}$ & 8 & : & $\stackrel{8}{\circ}$ & ले & 0 & m. & $\stackrel{\infty}{\circ}$ & $\stackrel{\text { }}{0}$ & 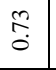 & $\vec{\jmath}$ & $\stackrel{\leftrightarrow}{\circ}$ & $\begin{array}{l}\infty \\
\infty \\
0\end{array}$ & $\begin{array}{l}0 \\
0\end{array}$ & $\begin{array}{l}\hat{0} \\
\hat{0}\end{array}$ & $\hat{\imath}$ & $\hat{\jmath}$ & $\stackrel{\leftrightarrow}{\circ}$ \\
\hline$\stackrel{\infty}{U}$ & $\overrightarrow{\widetilde{\partial}}$ & $\overrightarrow{\text { जे }}$ & $\overline{ }$ & $\stackrel{\widetilde{0}}{\circ}$ & ?: & $\stackrel{0}{0}$ & 0 & જે & $\stackrel{\leftrightarrow}{\circ}$ & خิ & $\stackrel{f}{\circ}$ & $\stackrel{\text { on }}{\circ}$ & જે & જે & $\begin{array}{l}0 \\
0 \\
0\end{array}$ & $\vec{\jmath}$ & $\begin{array}{l}\infty \\
\infty \\
0\end{array}$ & $\stackrel{\infty}{0}$ & $\begin{array}{l}\tilde{S} \\
0\end{array}$ & $\stackrel{2}{0}$ & $\stackrel{\overbrace{}}{0}$ & $\stackrel{2}{0}$ & $\stackrel{\tilde{o}}{0}$ \\
\hline$\stackrel{\partial}{0}$ & $\stackrel{8}{\circ}$ & $\stackrel{8}{\circ}$ & $\stackrel{8}{\circ}$ & 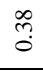 & 0 & $\stackrel{8}{\circ}$ & ְొ & $\stackrel{\circ}{\circ}$ & 0 & $\stackrel{\text { o. }}{\circ}$ & $0^{\circ}$ & $\stackrel{\text { o. }}{\circ}$ & 0 & f. & $\begin{array}{l}\infty \\
\infty \\
0 \\
0\end{array}$ & $\begin{array}{l}1 \\
\infty \\
0 \\
0\end{array}$ & $\hat{\hat{\theta}}$ & $\begin{array}{l}\infty \\
0 \\
0\end{array}$ & $\stackrel{8}{\circ}$ & $\stackrel{\infty}{0}$ & 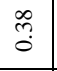 & तิ & $\stackrel{8}{0}$ \\
\hline రิ & $\overrightarrow{\widetilde{O}}$ & $\stackrel{\infty}{\circ}$ & $\frac{n}{0}$ & సิ & సิ & in & : & 홍 & $\begin{array}{l}\infty \\
\infty \\
\infty \\
\infty\end{array}$ & $\begin{array}{l}10 \\
\infty \\
0 \\
0\end{array}$ & $\stackrel{\overbrace{}}{0}$ & $\stackrel{\infty}{\circ}$ & œ & જે & $\begin{array}{l}\infty \\
\infty \\
\infty\end{array}$ & $\begin{array}{l}\infty \\
\infty \\
0\end{array}$ & $\hat{\hat{o}}$ & $\stackrel{\hat{o}}{\hat{0}}$ & $\hat{\imath}$ & ò & $\stackrel{\hat{\theta}}{\hat{0}}$ & $\stackrel{R}{0}$ & $\stackrel{\overbrace{}}{\circ}$ \\
\hline$\overline{\widetilde{U}}$ & $\begin{array}{l}n \\
0 \\
0\end{array}$ & : & f. & n. & $\stackrel{\infty}{\stackrel{\infty}{\circ}}$ & $\bar{\delta}$ & $\stackrel{\text { S. }}{\circ}$ & $\stackrel{\Re}{0}$ & : & $\stackrel{\text { o. }}{\circ}$ & $\begin{array}{l}0 \\
: \\
:\end{array}$ & $\stackrel{\infty}{\circ}$ & $\stackrel{\hat{o}}{\circ}$ & $\stackrel{\hat{o}}{\circ}$ & $\stackrel{\Re}{\circ}$ & 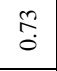 & $\begin{array}{l}\infty \\
\infty \\
0 \\
0\end{array}$ & $\begin{array}{l}\hat{0} \\
\vdots\end{array}$ & 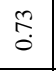 & $\begin{array}{l}\infty \\
\infty \\
0 \\
0\end{array}$ & $\stackrel{0}{0}$ & 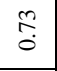 & $\stackrel{\overbrace{}}{\circ}$ \\
\hline ปี & $\begin{array}{l} \pm \\
0\end{array}$ & 㠻 & $\begin{array}{l}\infty \\
\infty \\
0\end{array}$ & $\underset{0}{f}$ & $\circ$ & જે & 0 & જે & $\circ$ & 0 & $\circ$ & 0 & $0^{\circ}$ & 0 & $\stackrel{\text { }}{\circ}$ & 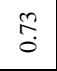 & 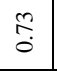 & ?̊. & 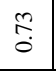 & 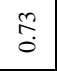 & $\overrightarrow{\widetilde{O}}$ & $\stackrel{8}{\circ}$ & 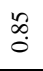 \\
\hline$\tilde{0}$ & $\begin{array}{l}\hat{\imath} \\
\hat{0}\end{array}$ & 㠻 & $\begin{array}{l}\infty \\
\infty \\
0\end{array}$ & $\hat{\delta}$ & 0 & $\stackrel{\overbrace{}}{0}$ & 0 & $\begin{array}{l}\infty \\
\infty \\
0\end{array}$ & $\dot{b}$ & 0 & $p$ & $\circ$ & $0^{\circ}$ & $\stackrel{\text { }}{0}$ & $\bar{\delta}$ & $\stackrel{+}{*}$ & $\stackrel{n}{0}$ & $\begin{array}{l}\vec{y} \\
\text {. }\end{array}$ & $\begin{array}{l}\tilde{0} \\
\stackrel{0}{0}\end{array}$ & 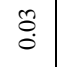 & $\begin{array}{l}0 \\
0 \\
0\end{array}$ & $\hat{\hat{o}}$ & $\stackrel{8}{\circ}$ \\
\hline
\end{tabular}


International Journal of Mathematical, Engineering and Management Sciences

Vol. 5, No. 4, 567-590, 2020

https://doi.org/10.33889/IJMEMS.2020.5.4.047

Table 13. Normalized direct relation matrix, $\mathrm{X}$

\begin{tabular}{|c|c|c|c|c|c|c|c|c|c|c|c|c|c|c|c|c|c|c|c|c|c|c|c|}
\hline$x$ & $\bar{U}$ & $\tilde{U}$ & 8 & U & 8 & 8 & $\hat{\theta}$ & 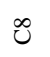 & 8 & $\stackrel{\circ}{U}$ & $\bar{u}$ & $\tilde{U}$ & $\stackrel{m}{U}$ & $\stackrel{\vec{U}}{U}$ & $\stackrel{n}{U}$ & $\stackrel{\bullet}{U}$ & $\bar{U}$ & $\stackrel{\infty}{U}$ & $\vec{U}$ & ठิ & $\overline{\widetilde{U}}$ & $\tilde{\widetilde{U}}$ & శิ \\
\hline $\bar{U}$ & $\stackrel{8}{0}$ & $\stackrel{n}{0}$ & to & $\stackrel{\leftrightarrow}{0}$ & $\begin{array}{l}n \\
0 \\
0\end{array}$ & $\stackrel{\circ}{\circ}$ & $\stackrel{\widetilde{c}}{0}$ & $\stackrel{2}{\circ}$ & $\stackrel{\widetilde{O}}{0}$ & $\stackrel{n}{0}$ & $\stackrel{n}{0}$ & $\stackrel{n}{0}$ & $\stackrel{n}{0}$ & $\stackrel{n}{0}$ & $\stackrel{\overbrace{}}{0}$ & $\stackrel{\tilde{O}}{\circ}$ & $\overrightarrow{\dot{O}}$ & $\overrightarrow{0}$ & $\overrightarrow{0}$ & $\overrightarrow{0}$ & $\begin{array}{c}\tilde{O} \\
0\end{array}$ & $\stackrel{\overbrace{}}{0}$ & $\stackrel{0}{0}$ \\
\hline$\tilde{U}$ & $\stackrel{n}{0}$ & 8 & $\stackrel{\delta}{0}$ & $\stackrel{\overbrace{}}{\circ}$ & $\begin{array}{l}n \\
0 \\
0\end{array}$ & $\stackrel{n}{\circ}$ & $\begin{array}{l}0 \\
0 \\
0\end{array}$ & $\stackrel{n}{0}$ & $\begin{array}{l}\overline{0} \\
0\end{array}$ & $\stackrel{n}{0}$ & $\stackrel{r}{0}$ & $\begin{array}{l}n \\
0 \\
0\end{array}$ & $\begin{array}{l}0 \\
0 \\
0\end{array}$ & $\stackrel{n}{0}$ & 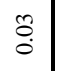 & $\stackrel{n}{0}$ & $\begin{array}{l}\tilde{O} \\
\dot{0}\end{array}$ & $\stackrel{8}{0}$ & $\stackrel{8}{0}$ & $\overrightarrow{0}$ & $\stackrel{8}{8}$ & $\stackrel{n}{0}$ & $\stackrel{0}{0}$ \\
\hline 8 & $\stackrel{n}{0}$ & 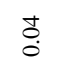 & 8 & $\stackrel{n}{\circ}$ & $\stackrel{8}{\circ}$ & $\stackrel{\circ}{\circ}$ & $\stackrel{8}{\circ}$ & $\stackrel{d}{0}$ & $\stackrel{\sigma}{0}$ & $\stackrel{8}{0}$ & $\stackrel{\because}{0}$ & $\stackrel{\overbrace{}}{0}$ & $\stackrel{8}{0}$ & 范 & $\stackrel{\because}{\circ}$ & $\stackrel{\check{0}}{\circ}$ & $\overline{0}$ & $\stackrel{t}{0}$ & $\tilde{\delta}$ & $\stackrel{\tilde{O}}{\circ}$ & $\begin{array}{l}0 \\
0 \\
0\end{array}$ & $\stackrel{\overbrace{}}{\circ}$ & 苟 \\
\hline U & $\stackrel{\tilde{O}}{0}$ & $\stackrel{\delta}{0}$ & $\stackrel{0}{\circ}$ & $\stackrel{8}{0}$ & $\stackrel{n}{0}$ & $\stackrel{t}{0}$ & $\stackrel{n}{0}$ & $\stackrel{n}{0}$ & $\begin{array}{c}1 \\
0 \\
0\end{array}$ & $\overrightarrow{0}$ & $\overline{0}$ & $\overrightarrow{0}$ & $\stackrel{n}{\circ}$ & $\stackrel{t}{\circ}$ & $\tilde{\delta}$ & $\stackrel{\tilde{O}}{\circ}$ & 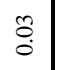 & $\stackrel{t}{0}$ & 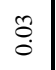 & $\stackrel{\tilde{O}}{\circ}$ & $\stackrel{8}{8}$ & $\begin{array}{l} \pm \\
0 \\
0\end{array}$ & $\stackrel{\leftrightarrow}{0}$ \\
\hline 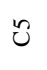 & $\stackrel{\circ}{0}$ & $\stackrel{\leftrightarrow}{0}$ & $\stackrel{t}{0}$ & $\stackrel{\leftrightarrow}{\circ}$ & $\stackrel{8}{0}$ & $\stackrel{8}{\circ}$ & $\stackrel{\circ}{0}$ & $\stackrel{8}{\circ}$ & $\overline{0}$ & $\stackrel{\leftrightarrow}{\circ}$ & $\begin{array}{l}0 \\
0 \\
0\end{array}$ & $\stackrel{\leftrightarrow}{\circ}$ & $\stackrel{0}{0}$ & $\stackrel{\leftrightarrow}{0}$ & $\stackrel{0}{0}$ & $\stackrel{\leftrightarrow}{\circ}$ & $\stackrel{\tilde{O}}{0}$ & $\stackrel{8}{\circ}$ & $\tilde{\delta}$ & $\stackrel{\leftrightarrow}{\circ}$ & $\stackrel{8}{0}$ & $\stackrel{8}{0}$ & $\stackrel{0}{\circ}$ \\
\hline 8 & $\stackrel{8}{0}$ & $\stackrel{\circ}{0}$ & $\stackrel{8}{\circ}$ & $\stackrel{n}{\circ}$ & $\begin{array}{l}t \\
0 \\
0\end{array}$ & $\stackrel{8}{\circ}$ & $\stackrel{\widetilde{c}}{\circ}$ & $\stackrel{n}{\circ}$ & $\overline{0}$ & $\stackrel{n}{0}$ & $\stackrel{d}{0}$ & $\stackrel{n}{0}$ & $\stackrel{n}{0}$ & $\stackrel{n}{0}$ & $\stackrel{\overbrace{}}{\circ}$ & $\stackrel{t}{0}$ & $\stackrel{\circ}{\circ}$ & $\stackrel{\tilde{\sigma}}{\circ}$ & $\stackrel{\tilde{O}}{\circ}$ & $\stackrel{\tilde{O}}{\circ}$ & $\stackrel{n}{:}$ & $\stackrel{d}{0}$ & $\stackrel{8}{\circ}$ \\
\hline E & $\stackrel{\leftrightarrow}{\circ}$ & $\stackrel{\overbrace{}}{\circ}$ & $\stackrel{8}{\circ}$ & $\stackrel{n}{0}$ & $\begin{array}{l} \pm \\
0 \\
0\end{array}$ & $\stackrel{n}{\circ}$ & 8 & $\stackrel{8}{\circ}$ & $\stackrel{d}{0}$ & $\overrightarrow{0}$ & $\stackrel{\delta}{0}$ & $\overrightarrow{0}$ & $\stackrel{\leftrightarrow}{0}$ & $\stackrel{8}{\circ}$ & $\stackrel{n}{0}$ & $\stackrel{d}{0}$ & $\stackrel{n}{0}$ & $\stackrel{d}{0}$ & $\begin{array}{l}\Delta \\
0 \\
0\end{array}$ & $\stackrel{\leftrightarrow}{\circ}$ & $\stackrel{n}{0}$ & $\stackrel{\circ}{0}$ & $\stackrel{0}{0}$ \\
\hline$\ddot{0}$ & $\stackrel{0}{0}$ & 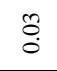 & $\stackrel{0}{0}$ & $\stackrel{\tilde{O}}{0}$ & $\begin{array}{c}0 \\
0 \\
0\end{array}$ & $\stackrel{8}{\circ}$ & $\stackrel{\infty}{\circ}$ & $\stackrel{8}{0}$ & $\overrightarrow{\dot{0}}$ & $\stackrel{8}{0}$ & $\begin{array}{l}\tilde{O} \\
0\end{array}$ & $\stackrel{8}{0}$ & $\stackrel{\infty}{\circ}$ & d & 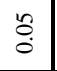 & 苛 & $\dot{0}$ & $\begin{array}{l}\Delta \\
0\end{array}$ & $\begin{array}{l} \pm \\
0 \\
0\end{array}$ & 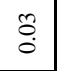 & $\begin{array}{l} \pm \\
0 \\
0\end{array}$ & $\stackrel{n}{0}$ & 苛 \\
\hline 8 & $\stackrel{\leftrightarrow}{\circ}$ & $\stackrel{t}{0}$ & $\stackrel{n}{0}$ & $\stackrel{\leftrightarrow}{0}$ & $\stackrel{n}{0}$ & $\stackrel{n}{\circ}$ & $\stackrel{n}{0}$ & $\stackrel{n}{0}$ & $\stackrel{8}{0}$ & $\stackrel{\leftrightarrow}{\circ}$ & $\stackrel{8}{\circ}$ & $\stackrel{n}{0}$ & $\begin{array}{l}0 \\
0 \\
0\end{array}$ & $\stackrel{\leftrightarrow}{\circ}$ & $\stackrel{n}{0}$ & $\stackrel{\leftrightarrow}{0}$ & $\stackrel{n}{0}$ & $\stackrel{\mathscr{c}}{0}$ & $\stackrel{8}{\circ}$ & $\stackrel{\check{0}}{\circ}$ & $\stackrel{8}{\circ}$ & $\stackrel{d}{0}$ & $\stackrel{\circ}{\circ}$ \\
\hline$\stackrel{8}{0}$ & $\begin{array}{l}0 \\
0 \\
0\end{array}$ & $\stackrel{\leftrightarrow}{0}$ & 8 & $\overrightarrow{0}$ & $\begin{array}{l}8 \\
0\end{array}$ & $\ddot{\circ}$ & 8 & $\overrightarrow{0}$ & 8 & 8 & $\stackrel{0}{\circ}$ & $\begin{array}{l}n \\
0 \\
0\end{array}$ & $\stackrel{8}{0}$ & $\overrightarrow{0}$ & $\begin{array}{l}0 \\
0 \\
0\end{array}$ & $\stackrel{\tilde{O}}{0}$ & $\begin{array}{l}\tilde{O} \\
\delta \\
\delta\end{array}$ & $\overrightarrow{0}$ & $\begin{array}{l}0 \\
0\end{array}$ & $\begin{array}{l}0 \\
0 \\
0\end{array}$ & $\begin{array}{l}0 \\
\stackrel{0}{0}\end{array}$ & $\stackrel{\mathscr{0}}{0}$ & $\stackrel{8}{\circ}$ \\
\hline $\bar{u}$ & $\stackrel{\leftrightarrow}{0}$ & $\stackrel{t}{0}$ & $\stackrel{8}{0}$ & $\stackrel{\tilde{O}}{\circ}$ & $\stackrel{d}{0}$ & ठ̊. & $\stackrel{n}{0}$ & $\stackrel{8}{\circ}$ & 8 & $\stackrel{n}{0}$ & $\stackrel{8}{0}$ & $\stackrel{n}{0}$ & $\stackrel{d}{0}$ & $\stackrel{\tilde{o}}{\circ}$ & $\stackrel{\leftrightarrow}{\circ}$ & $\stackrel{\leftrightarrow}{0}$ & $\tilde{o}_{0}$ & $\stackrel{\tilde{o}}{\circ}$ & $\stackrel{\tilde{O}}{\delta}$ & $\stackrel{\overbrace{}}{\circ}$ & $\tilde{O}$ & $\stackrel{\check{0}}{\circ}$ & $\bar{\circ}$ \\
\hline$\stackrel{\simeq}{U}$ & $\stackrel{\leftrightarrow}{0}$ & 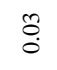 & $\stackrel{t}{0}$ & $\stackrel{\leftrightarrow}{\circ}$ & $\stackrel{8}{\circ}$ & $\stackrel{8}{\circ}$ & $\stackrel{\leftrightarrow}{\circ}$ & $\stackrel{\leftrightarrow}{\circ}$ & $\stackrel{0}{0}$ & $\stackrel{n}{0}$ & $\stackrel{0}{0}$ & 8 & $\stackrel{8}{\circ}$ & $\stackrel{8}{\circ}$ & $\stackrel{0}{0}$ & $\stackrel{\leftrightarrow}{0}$ & $\tilde{O}$ & $\stackrel{\leftrightarrow}{\circ}$ & $\stackrel{0}{0}$ & $\stackrel{2}{0}$ & $\stackrel{8}{\circ}$ & $\overrightarrow{0}$ & $\stackrel{8}{0}$ \\
\hline$\stackrel{m}{U}$ & $\stackrel{n}{0}$ & $\stackrel{8}{0}$ & $\stackrel{\overbrace{}}{\circ}$ & $\stackrel{n}{\circ}$ & $\stackrel{n}{0}$ & $\stackrel{\circ}{\circ}$ & $\stackrel{n}{0}$ & $\stackrel{n}{\circ}$ & $\begin{array}{l}0 \\
0 \\
0\end{array}$ & $\stackrel{d}{0}$ & $\begin{array}{l}0 \\
0 \\
0\end{array}$ & $\stackrel{t}{0}$ & $\stackrel{8}{0}$ & $\stackrel{\circ}{\circ}$ & $\stackrel{8}{8}$ & $\stackrel{\leftrightarrow}{\circ}$ & $\stackrel{8}{\circ}$ & $\stackrel{n}{0}$ & $\stackrel{n}{0}$ & $\begin{array}{l} \pm \\
0 \\
0\end{array}$ & $\stackrel{8}{\circ}$ & $\stackrel{n}{0}$ & $\stackrel{\circ}{\circ}$ \\
\hline$\underset{\tau}{U}$ & $\stackrel{8}{0}$ & $\stackrel{\leftrightarrow}{\circ}$ & $\stackrel{8}{\circ}$ & $\stackrel{n}{0}$ & $\begin{array}{l}n \\
:\end{array}$ & $\stackrel{8}{\circ}$ & $\stackrel{n}{0}$ & $\stackrel{n}{\circ}$ & $\begin{array}{l}t \\
\dot{0} \\
\dot{0}\end{array}$ & $\begin{array}{l}\dot{0} \\
\dot{0}\end{array}$ & $\begin{array}{l}0 \\
0 \\
0\end{array}$ & $\stackrel{\infty}{\circ}$ & $\stackrel{n}{0}$ & $\stackrel{8}{0}$ & $\stackrel{n}{0}$ & 苞 & 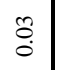 & $\stackrel{n}{0}$ & $\stackrel{n}{\circ}$ & $\stackrel{\mathscr{0}}{\circ}$ & $\stackrel{8}{\circ}$ & $\stackrel{n}{0}$ & $\stackrel{0}{\circ}$ \\
\hline$\stackrel{n}{U}$ & 范 & $\stackrel{t}{0}$ & t & $\stackrel{\delta}{0}$ & $\stackrel{8}{\circ}$ & $\stackrel{\circ}{\circ}$ & $\stackrel{t}{0}$ & $\stackrel{d}{0}$ & $\stackrel{\text { of }}{0}$ & $\stackrel{\delta}{0}$ & $\stackrel{8}{\circ}$ & $\stackrel{\delta}{0}$ & $\stackrel{8}{\circ}$ & $\stackrel{\circ}{0}$ & $\stackrel{8}{0}$ & $\stackrel{\circ}{0}$ & $\stackrel{\circ}{\circ}$ & $\stackrel{8}{\circ}$ & $\stackrel{8}{\circ}$ & $\stackrel{\overbrace{}}{\circ}$ & $\stackrel{\leftrightarrow}{\circ}$ & $\stackrel{8}{\circ}$ & $\stackrel{\circ}{\circ}$ \\
\hline$\stackrel{0}{u}$ & $\begin{array}{l}\Delta \\
0 \\
0\end{array}$ & $\stackrel{n}{0}$ & $\stackrel{\leftrightarrow}{\circ}$ & $\stackrel{8}{\circ}$ & $\begin{array}{c}0 \\
0 \\
0\end{array}$ & $\stackrel{\text { SO }}{\circ}$ & $\stackrel{0}{0}$ & $\stackrel{\overrightarrow{0}}{\circ}$ & $\begin{array}{l}\Delta \\
0 \\
0\end{array}$ & $\stackrel{\delta}{\circ}$ & $\begin{array}{l}\tilde{O} \\
\delta\end{array}$ & $\begin{array}{l}\Delta \\
0 \\
0\end{array}$ & $\stackrel{0}{0}$ & $\begin{array}{l}\Delta \\
0\end{array}$ & $\stackrel{0}{0}$ & $\stackrel{8}{0}$ & $\stackrel{\overrightarrow{0}}{\circ}$ & $\stackrel{\tilde{O}}{\circ}$ & $\stackrel{0}{0}$ & $\stackrel{8}{\circ}$ & $\stackrel{8}{\circ}$ & $\stackrel{8}{\circ}$ & ठ̊. \\
\hline$\tilde{U}$ & $\overrightarrow{0}$ & 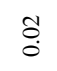 & $\overline{0}$ & $\stackrel{\tilde{\sigma}}{0}$ & $\stackrel{\overbrace{}}{:}$ & $\stackrel{8}{\circ}$ & $\begin{array}{l}0 \\
0 \\
0\end{array}$ & $\stackrel{\overbrace{}}{\circ}$ & $\stackrel{8}{0}$ & $\stackrel{\widetilde{\sigma}}{0}$ & $\stackrel{8}{0}$ & $\stackrel{\widetilde{\sigma}}{0}$ & $\begin{array}{l}0 \\
0 \\
0\end{array}$ & $\stackrel{n}{0}$ & $\stackrel{\because}{\circ}$ & $\overrightarrow{0}$ & $\stackrel{8}{0}$ & 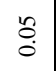 & $\div$ & $\stackrel{\because}{0}$ & $\stackrel{n}{:}$ & $\stackrel{\because}{0}$ & $\stackrel{0}{0}$ \\
\hline$\stackrel{\infty}{\mathcal{U}}$ & $\overrightarrow{0}$ & $\overrightarrow{0}$ & $\overline{0}$ & $\stackrel{d}{0}$ & $\stackrel{8}{\circ}$ & $\stackrel{8}{0}$ & $\stackrel{n}{0}$ & $\stackrel{n}{0}$ & $\stackrel{8}{0}$ & $\begin{array}{l}\tilde{O} \\
\dot{0}\end{array}$ & $\stackrel{8}{8}$ & 8 & $\begin{array}{l}0 \\
0 \\
0\end{array}$ & $\stackrel{n}{0}$ & $\begin{array}{l}0 \\
0 \\
0\end{array}$ & $\overrightarrow{0}$ & $\stackrel{n}{0}$ & $\stackrel{8}{0}$ & $\begin{array}{l}\dot{d} \\
\dot{0} \\
0\end{array}$ & $\stackrel{n}{0}$ & $\begin{array}{l}n \\
0 \\
0\end{array}$ & $\stackrel{n}{0}$ & $\stackrel{0}{0}$ \\
\hline $\overrightarrow{\mathrm{U}}$ & $\stackrel{8}{0}$ & $\stackrel{8}{0}$ & $\stackrel{0}{0}$ & $\stackrel{\leftrightarrow}{\circ}$ & $\stackrel{0}{0}$ & $\stackrel{8}{\circ}$ & $\stackrel{\sim}{0}$ & $\stackrel{d}{0}$ & $\stackrel{8}{\circ}$ & $\stackrel{8}{0}$ & $\stackrel{\delta}{0}$ & $\stackrel{8}{0}$ & $\stackrel{0}{0}$ & $\stackrel{\leftrightarrow}{\circ}$ & $\stackrel{0}{0}$ & $\stackrel{\leftrightarrow}{0}$ & $\stackrel{0}{0}$ & $\stackrel{t}{0}$ & $\stackrel{8}{0}$ & $\stackrel{\leftrightarrow}{\circ}$ & $\stackrel{\tilde{O}}{0}$ & $\stackrel{0}{\circ}$ & $\stackrel{\overbrace{}}{0}$ \\
\hline రิ & $\overrightarrow{0}$ & d़ & $\overline{0}$ & $\stackrel{\delta}{\circ}$ & $\begin{array}{l}\tilde{O} \\
\delta\end{array}$ & $\stackrel{8}{\circ}$ & $\stackrel{8}{\circ}$ & $\stackrel{\tilde{O}}{0}$ & $\stackrel{n}{0}$ & $\stackrel{n}{0}$ & $\stackrel{n}{0}$ & $\begin{array}{l}\Delta \\
0 \\
0\end{array}$ & $\stackrel{\leftrightarrow}{0}$ & $\stackrel{n}{0}$ & $\begin{array}{l}n \\
0 \\
0\end{array}$ & $\stackrel{n}{0}$ & $\stackrel{n}{0}$ & $\stackrel{\mathscr{c}}{0}$ & $\stackrel{8}{0}$ & $\overrightarrow{0}$ & $\stackrel{n}{0}$ & $\stackrel{n}{0}$ & $\stackrel{0}{0}$ \\
\hline $\overrightarrow{\widetilde{U}}$ & $\stackrel{\leftrightarrow}{0}$ & $\stackrel{\overbrace{}}{0}$ & $\stackrel{\circ}{\circ}$ & $\stackrel{\overbrace{}}{\circ}$ & $\begin{array}{l}\Delta \\
0 \\
0\end{array}$ & $\stackrel{8}{\circ}$ & $\stackrel{t}{0}$ & $\stackrel{0}{0}$ & $\stackrel{\leftrightarrow}{0}$ & $\stackrel{8}{0}$ & $\stackrel{0}{0}$ & $\stackrel{t}{0}$ & $\stackrel{0}{0}$ & $\stackrel{\leftrightarrow}{0}$ & $\stackrel{0}{0}$ & $\stackrel{\leftrightarrow}{0}$ & $\stackrel{0}{0}$ & $\stackrel{\ddot{0}}{0}$ & $\stackrel{8}{0}$ & $\stackrel{\check{0}}{0}$ & $\overline{0}$ & $\stackrel{\circ}{0}$ & $\stackrel{0}{\circ}$ \\
\hline$\tilde{\Xi}$ & $\stackrel{8}{0}$ & $\stackrel{8}{\circ}$ & 8 & $\stackrel{8}{\circ}$ & $\stackrel{8}{\circ}$ & $\stackrel{8}{\circ}$ & $\stackrel{n}{0}$ & $\stackrel{8}{0}$ & $\begin{array}{l}\tilde{0} \\
\dot{0}\end{array}$ & $\overrightarrow{0}$ & $\stackrel{8}{\circ}$ & $\stackrel{0}{0}$ & $\stackrel{+}{0}$ & $\stackrel{\circ}{\circ}$ & $\stackrel{8}{\circ}$ & $\stackrel{n}{\circ}$ & $\stackrel{8}{\circ}$ & $\stackrel{8}{0}$ & $\stackrel{n}{8}$ & $\stackrel{8}{\circ}$ & $\dot{0}$ & 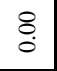 & $\stackrel{0}{\circ}$ \\
\hline$\widetilde{U}$ & $\stackrel{\circ}{0}$ & $\stackrel{\overbrace{}}{0}$ & $\stackrel{\circ}{0}$ & $\stackrel{\leftrightarrow}{\circ}$ & $\stackrel{n}{0}$ & $\stackrel{8}{\circ}$ & $\stackrel{\circ}{\circ}$ & $\stackrel{8}{\circ}$ & $\stackrel{0}{0}$ & $\stackrel{\delta}{0}$ & $\stackrel{8}{\circ}$ & $\overrightarrow{0}$ & $\stackrel{0}{0}$ & $\stackrel{\leftrightarrow}{0}$ & $\stackrel{0}{0}$ & $\stackrel{\overbrace{}}{0}$ & $\overline{0}$ & $\overrightarrow{0}$ & 8 & $\stackrel{8}{0}$ & $\stackrel{8}{\circ}$ & $\ddot{0}$ & o. \\
\hline
\end{tabular}


International Journal of Mathematical, Engineering and Management Sciences

Vol. 5, No. 4, 567-590, 2020

https://doi.org/10.33889/IJMEMS.2020.5.4.047

Table 14. Total relation matrix, $\mathrm{T}$

\begin{tabular}{|c|c|c|c|c|c|c|c|c|c|c|c|c|c|c|c|c|c|c|c|c|c|c|c|}
\hline$H$ & $\bar{U}$ & $\widetilde{U}$ & 8 & đ & 8 & 8 & $\hat{\theta}$ & 0 & 8 & $\stackrel{\ominus}{u}$ & $\bar{u}$ & ปี & $\vec{u}$ & $\stackrel{\vec{U}}{U}$ & $\frac{n}{u}$ & $\stackrel{\bullet}{u}$ & $\bar{U}$ & $\stackrel{\infty}{U}$ & $\overrightarrow{\mathrm{U}}$ & రิ & $\overline{\widetilde{U}}$ & $\tilde{U}$ & $\tilde{\delta}$ \\
\hline $\bar{U}$ & $\dddot{7}$ & $\stackrel{0}{0}$ & $\stackrel{9}{0}$ & $\stackrel{ \pm}{0}$ & $\begin{array}{l}0 \\
0\end{array}$ & $\stackrel{5}{0}$ & $\frac{n}{0}$ & $\frac{\infty}{0}$ & oे & $\stackrel{ \pm}{0}$ & $\stackrel{0}{0}$ & $\stackrel{ \pm}{0}$ & $\frac{7}{0}$ & $\stackrel{\infty}{0}$ & $\frac{0}{0}$ & $\stackrel{ \pm}{0}$ & $\begin{array}{l}0 \\
0\end{array}$ & $\stackrel{\circ}{\circ}$ & $\stackrel{\circ}{0}$ & $\stackrel{\circ}{\circ}$ & $\stackrel{m}{0}$ & $\stackrel{ \pm}{0}$ & $\frac{0}{0}$ \\
\hline ชี & $\stackrel{7}{0}$ & $\frac{9}{0}$ & $\bar{z}$ & $\stackrel{ \pm}{0}$ & \begin{tabular}{l|}
$\div$ \\
0
\end{tabular} & $\stackrel{7}{0}$ & \begin{tabular}{l|}
$\stackrel{0}{0}$ \\
\end{tabular} & 7 & $\begin{array}{l} \\
0 \\
0\end{array}$ & $\begin{array}{l} \pm \\
\end{array}$ & $\begin{array}{l}0 \\
0 \\
0\end{array}$ & $\begin{array}{l} \pm \\
\end{array}$ & 7 & $\begin{array}{l}\infty \\
0\end{array}$ & $\begin{array}{l} \\
\end{array}$ & $\frac{0}{0}$ & $\overline{0}$ & $\stackrel{9}{\circ}$ & $\begin{array}{l}\circ \\
\end{array}$ & $\overline{0}$ & \begin{tabular}{l|} 
\pm \\
\end{tabular} & $\begin{array}{l}0 \\
0\end{array}$ & $\frac{10}{0}$ \\
\hline$\delta$ & $\stackrel{5}{0}$ & $\frac{0}{0}$ & $\stackrel{\circ}{\circ}$ & $\stackrel{9}{0}$ & $\begin{array}{l}\infty \\
0\end{array}$ & $\stackrel{\infty}{0}$ & $\frac{9}{0}$ & $\stackrel{\infty}{0}$ & $\stackrel{0}{\circ}$ & $\frac{m}{0}$ & $\stackrel{7}{0}$ & $\stackrel{ \pm}{0}$ & $\frac{\infty}{0}$ & $\stackrel{\infty}{0}$ & $\frac{9}{0}$ & $\stackrel{n}{0}$ & $\frac{0}{0}$ & $\stackrel{n}{0}$ & $\stackrel{7}{0}$ & $\stackrel{7}{0}$ & $\begin{array}{l}n \\
0 \\
0\end{array}$ & $\begin{array}{l}0 \\
0 \\
0\end{array}$ & $\stackrel{7}{0}$ \\
\hline J & $\overline{0}$ & $\overline{\overline{0}}$ & $\begin{array}{l} \\
0 \\
0\end{array}$ & ôे & $\begin{array}{l} \pm \\
\end{array}$ & $\frac{t}{0}$ & \begin{tabular}{l|}
$n$ \\
0
\end{tabular} & $\frac{0}{0}$ & $\begin{array}{l}0 \\
0 \\
0\end{array}$ & $\begin{array}{l}\infty \\
0 \\
0\end{array}$ & $\%$ & $\begin{array}{l}\infty \\
0 \\
0\end{array}$ & $\begin{array}{l}0 \\
0\end{array}$ & $\frac{n}{0}$ & $\frac{m}{0}$ & $\overline{0}$ & $\overline{7}$ & $\frac{1}{0}$ & $\overline{\overline{0}}$ & $\stackrel{\circ}{\circ}$ & 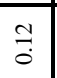 & $\begin{array}{l} \\
\end{array}$ & $\frac{m}{0}$ \\
\hline r & $\overline{0}$ & $\overline{0}$ & $\begin{array}{l}9 \\
0\end{array}$ & $\frac{0}{0}$ & $\begin{array}{l}m \\
0\end{array}$ & $\frac{\infty}{0}$ & \begin{tabular}{l|}
$\infty$ \\
\end{tabular} & $\frac{9}{0}$ & $\begin{array}{l} \\
0 \\
0\end{array}$ & $\because$ & $\because$ & $\stackrel{m}{0}$ & $\frac{\infty}{0}$ & $\frac{9}{0}$ & $\stackrel{7}{0}$ & $\frac{n}{0}$ & $\because$ & $\frac{m}{0}$ & $\because$ & $\because$ & $\begin{array}{l}n \\
0\end{array}$ & $\stackrel{0}{0}$ & $\stackrel{0}{0}$ \\
\hline 8 & $\stackrel{\infty}{0}$ & $\stackrel{\infty}{0}$ & $\cong$ & $\leftrightarrows$ & $\stackrel{\circ}{0}$ & $\stackrel{m}{0}$ & $\stackrel{0}{\circ}$ & $\frac{\infty}{0}$ & $\stackrel{0}{0}$ & $\stackrel{ \pm}{0}$ & $\stackrel{0}{\circ}$ & $\stackrel{n}{0}$ & $\frac{9}{0}$ & $\frac{\partial}{0}$ & 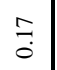 & $\stackrel{\circ}{0}$ & $\frac{0}{0}$ & $\stackrel{m}{0}$ & $\cong$ & $\because$ & $\stackrel{0}{0}$ & $\stackrel{0}{0}$ & $\stackrel{0}{\circ}$ \\
\hline E & $\frac{0}{0}$ & $\stackrel{0}{0}$ & $\frac{m}{0}$ & $\frac{7}{0}$ & $\begin{array}{l}7 \\
0\end{array}$ & $\stackrel{\infty}{0}$ & $\begin{array}{l} \pm \\
\end{array}$ & તิ & $\stackrel{\circ}{\circ}$ & $\overline{7}$ & $\frac{n}{0}$ & $\stackrel{7}{0}$ & $\begin{array}{l}\text { तิ } \\
\text { O }\end{array}$ & $\overrightarrow{\widehat{\jmath}}$ & \begin{tabular}{l}
\multirow{0}{0}{} \\
\end{tabular} & $\stackrel{7}{0}$ & $\frac{ \pm}{0}$ & $\frac{n}{0}$ & $\frac{ \pm}{0}$ & $\stackrel{ \pm}{0}$ & $\begin{array}{l}0 \\
0\end{array}$ & $\stackrel{\infty}{0}$ & $\stackrel{\infty}{0}$ \\
\hline$\ddot{0}$ & $\stackrel{9}{0}$ & $\stackrel{9}{9}$ & $\stackrel{\circ}{\circ}$ & $\stackrel{9}{0}$ & $\stackrel{m}{0}$ & $\stackrel{0}{0}$ & $\begin{array}{l} \pm \\
\end{array}$ & $\stackrel{0}{\circ}$ & $\begin{array}{l} \\
0 \\
0\end{array}$ & $=$ & $\frac{m}{0}$ & $\overline{0}$ & $\begin{array}{l}0 \\
0\end{array}$ & $\begin{array}{l}0 \\
0 \\
0\end{array}$ & $\stackrel{7}{0}$ & $\begin{array}{l} \pm \\
\end{array}$ & $\stackrel{8}{\circ}$ & $\stackrel{m}{0}$ & $\stackrel{7}{0}$ & $\stackrel{0}{\circ}$ & $\underset{0}{ \pm}$ & $\begin{array}{l}2 \\
0 \\
0\end{array}$ & $\frac{n}{0}$ \\
\hline 8 & $\frac{\infty}{0}$ & $\frac{\infty}{0}$ & $\begin{array}{l}0 \\
0\end{array}$ & $\frac{9}{0}$ & $\frac{\vartheta}{0}$ & ֻิ & 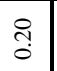 & $\overline{\tilde{O}}$ & $\begin{array}{l}0 \\
0 \\
0\end{array}$ & $\frac{n}{0}$ & $\frac{7}{0}$ & $\stackrel{0}{0}$ & $\begin{array}{l}\text { तิ } \\
0\end{array}$ & $\overrightarrow{\widehat{\partial}}$ & $\overline{\widetilde{N}}$ & $\frac{9}{0}$ & $\frac{n}{0}$ & 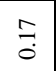 & $\frac{n}{0}$ & $\stackrel{ \pm}{0}$ & $\frac{0}{0}$ & $\frac{9}{0}$ & $\frac{\vartheta}{0}$ \\
\hline$\stackrel{\Xi}{0}$ & $\stackrel{7}{0}$ & $\stackrel{m}{0}$ & $\begin{array}{l}0 \\
0 \\
0\end{array}$ & $\stackrel{\infty}{0}$ & $\begin{array}{l}0 \\
0 \\
0 \\
0\end{array}$ & $\stackrel{8}{0}$ & $\begin{array}{l}0 \\
0 \\
0\end{array}$ & $\stackrel{\circ}{\circ}$ & $\begin{array}{l}n \\
0 \\
0\end{array}$ & $\begin{array}{l}0 \\
0 \\
0\end{array}$ & $\frac{ \pm}{0}$ & $\stackrel{7}{0}$ & $\cong$ & $\stackrel{\circ}{0}$ & $\because$ & $\stackrel{\circ}{\circ}$ & $\begin{array}{l}\infty \\
0 \\
0\end{array}$ & $\begin{array}{l}\infty \\
0 \\
0\end{array}$ & $\begin{array}{l}\infty \\
0 \\
0\end{array}$ & $\exists$ & $\stackrel{\circ}{\circ}$ & $\exists$ & 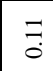 \\
\hline $\bar{u}$ & $\frac{n}{0}$ & $\begin{array}{l} \pm \\
\end{array}$ & $\frac{9}{0}$ & $\exists$ & 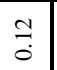 & $\stackrel{7}{0}$ & $\begin{array}{l}n \\
0\end{array}$ & $\stackrel{ \pm}{0}$ & $\begin{array}{l}0 \\
0 \\
0\end{array}$ & $\stackrel{7}{0}$ & $\stackrel{0}{\circ}$ & $\stackrel{9}{0}$ & $\frac{9}{0}$ & $\stackrel{9}{0}$ & $\frac{ \pm}{0}$ & $\stackrel{ \pm}{0}$ & $\begin{array}{l}0 \\
0 \\
0\end{array}$ & $\stackrel{\circ}{\circ}$ & $\stackrel{\circ}{\circ}$ & $\because$ & $\bar{z}$ & $\because$ & $\overline{0}$ \\
\hline$\Xi$ & $\stackrel{0}{0}$ & $\frac{m}{0}$ & $\cong$ & $\stackrel{\div}{0}$ & $\stackrel{ \pm}{0}$ & $\frac{n}{0}$ & $\stackrel{ \pm}{0}$ & $\frac{m}{0}$ & oे & $\frac{m}{0}$ & $\frac{n}{0}$ & $\stackrel{a}{0}$ & $\frac{n}{0}$ & $\stackrel{ \pm}{0}$ & $\frac{ \pm}{0}$ & $\stackrel{n}{0}$ & $\stackrel{0}{0}$ & $\exists$ & $\frac{0}{0}$ & $\stackrel{9}{0}$ & $\stackrel{m}{0}$ & $\because$ & $\overline{0}$ \\
\hline$\vec{U}$ & 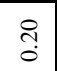 & 离 & $\begin{array}{l} \pm \\
\end{array}$ & $\frac{9}{0}$ & בัণ & $\overline{\mathrm{\jmath}}$ & $\overline{|c|}$ & ปี & $\frac{m}{0}$ & $\begin{array}{l}0 \\
0\end{array}$ & $\frac{9}{0}$ & $\stackrel{0}{0}$ & $\frac{\infty}{0}$ & तु & $\overline{\bar{\Im}}$ & $\frac{\infty}{0}$ & $\frac{7}{0}$ & $\stackrel{\infty}{0}$ & $\frac{7}{0}$ & $\begin{array}{l}0 \\
0 \\
0\end{array}$ & $\stackrel{7}{0}$ & 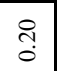 & ণิ \\
\hline$\vec{U}$ & ণิ & ণิ & $\begin{array}{l} \pm \\
0\end{array}$ & $\frac{\infty}{0}$ & $\begin{array}{l}\text { ণิ } \\
0\end{array}$ & $\overline{\tilde{O}}$ & $\begin{array}{l}\vec{N} \\
0\end{array}$ & $\begin{array}{l}\text { त̃ } \\
0\end{array}$ & $\frac{m}{0}$ & $\stackrel{0}{0}$ & $\frac{\infty}{0}$ & $\stackrel{0}{0}$ & $\begin{array}{l}\text { İ } \\
0\end{array}$ & $\stackrel{7}{0}$ & $\begin{array}{l}\bar{\pi} \\
0\end{array}$ & $\stackrel{\infty}{0}$ & $\begin{array}{l}n \\
0\end{array}$ & $\stackrel{7}{0}$ & $\begin{array}{l}0 \\
0\end{array}$ & $\stackrel{0}{0}$ & $\begin{array}{l}7 \\
0\end{array}$ & ণิ & ֻัণิ \\
\hline$\tilde{u}$ & $\stackrel{n}{0}$ & $\stackrel{0}{0}$ & $\frac{m}{0}$ & $\frac{m}{0}$ & $\frac{n}{0}$ & $\stackrel{5}{0}$ & $\stackrel{0}{\circ}$ & $\stackrel{7}{0}$ & $\cong$ & $\vec{F}$ & $\stackrel{ \pm}{0}$ & $\stackrel{7}{0}$ & $\stackrel{\infty}{0}$ & $\stackrel{\infty}{0}$ & $\frac{m}{0}$ & $\stackrel{0}{0}$ & $\frac{0}{0}$ & $\stackrel{m}{0}$ & $\cong$ & $\stackrel{m}{0}$ & $\stackrel{m}{0}$ & $\stackrel{n}{0}$ & $\frac{n}{0}$ \\
\hline$\ddot{U}$ & $\begin{array}{l} \pm \\
\end{array}$ & $\begin{array}{l}n \\
0\end{array}$ & $\begin{array}{l} \\
\end{array}$ & $\frac{m}{0}$ & $\begin{array}{l}m \\
0\end{array}$ & $\because$ & $\begin{array}{l}m \\
0\end{array}$ & $\because$ & $\stackrel{9}{\circ}$ & $\stackrel{9}{\circ}$ & $\because$ & $\frac{7}{0}$ & $\begin{array}{l}n \\
0\end{array}$ & $\frac{n}{0}$ & $\frac{7}{0}$ & $\stackrel{9}{\circ}$ & \begin{tabular}{l|} 
\\
0 \\
0
\end{tabular} & $\bar{z}$ & $\frac{7}{0}$ & $\because$ & $\begin{array}{l}m \\
0\end{array}$ & $\frac{9}{0}$ & $\frac{m}{0}$ \\
\hline$\Xi$ & $\because$ & $\frac{m}{0}$ & $\begin{array}{l}0 \\
0 \\
0\end{array}$ & $\stackrel{\div}{0}$ & $\stackrel{ \pm}{0}$ & $\overline{0}$ & $\frac{n}{0}$ & $\frac{n}{0}$ & $\begin{array}{l}0 \\
0 \\
0\end{array}$ & $\stackrel{0}{0}$ & $\frac{m}{0}$ & $\stackrel{\circ}{0}$ & $\stackrel{0}{0}$ & 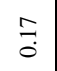 & 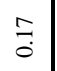 & $\stackrel{7}{0}$ & $\stackrel{0}{0}$ & $\stackrel{ \pm}{0}$ & $\frac{m}{0}$ & $\stackrel{ \pm}{0}$ & $\frac{n}{0}$ & $\stackrel{0}{0}$ & $\frac{n}{0}$ \\
\hline$\stackrel{\infty}{U}$ & $\frac{7}{0}$ & $\frac{7}{0}$ & $\stackrel{8}{0}$ & $\stackrel{ \pm}{0}$ & $\stackrel{ \pm}{0}$ & $=$ & $\stackrel{0}{\circ}$ & $\stackrel{7}{0}$ & $\begin{array}{c}0 \\
0 \\
0\end{array}$ & 0 & $\frac{m}{0}$ & $\begin{array}{l}o \\
0 \\
0\end{array}$ & $\stackrel{7}{0}$ & $\stackrel{亏}{0}$ & $\frac{0}{0}$ & $\frac{7}{0}$ & $\frac{m}{0}$ & $\stackrel{0}{0}$ & $\frac{m}{0}$ & $\stackrel{m}{0}$ & $\stackrel{ \pm}{0}$ & $\stackrel{n}{0}$ & $\stackrel{n}{0}$ \\
\hline$\stackrel{\partial}{\partial}$ & $\begin{array}{l}\infty \\
0 \\
0\end{array}$ & $\begin{array}{l}\infty \\
0 \\
0\end{array}$ & $\begin{array}{l}0 \\
0 \\
0\end{array}$ & $\stackrel{0}{0}$ & oे & $\stackrel{\infty}{\circ}$ & $=$ & $\stackrel{\simeq}{\circ}$ & $\stackrel{0}{0}$ & $\stackrel{0}{\circ}$ & $\stackrel{\circ}{\circ}$ & $\stackrel{8}{0}$ & $\cong$ & $\stackrel{7}{0}$ & $\stackrel{ \pm}{0}$ & $\stackrel{m}{0}$ & $=$ & $\exists$ & $\begin{array}{l}0 \\
0 \\
0\end{array}$ & $\stackrel{0}{0}$ & oे & $\stackrel{0}{0}$ & $=$ \\
\hline ปิ & $\stackrel{n}{0}$ & $\stackrel{7}{0}$ & $\bar{Z}$ & $\stackrel{t}{0}$ & $\begin{array}{l}n \\
0 \\
0\end{array}$ & 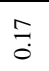 & $\begin{array}{l}7 \\
0\end{array}$ & $\stackrel{0}{0}$ & $\frac{m}{0}$ & $\stackrel{n}{0}$ & $\frac{7}{0}$ & $\stackrel{n}{0}$ & $\begin{array}{l}\text { đิ } \\
\text { ○ }\end{array}$ & ֻิ & \begin{tabular}{l}
\multirow{0}{0}{} \\
\end{tabular} & $\stackrel{\infty}{0}$ & $\frac{n}{0}$ & $\begin{array}{l}0 \\
0\end{array}$ & $\begin{array}{l}0 \\
0\end{array}$ & $\because$ & $\stackrel{7}{0}$ & $\stackrel{\infty}{0}$ & $\stackrel{\infty}{0}$ \\
\hline$\overline{\mathrm{U}}$ & $\stackrel{5}{0}$ & $\overline{0}$ & $\frac{m}{0}$ & $\stackrel{0}{0}$ & $\stackrel{\infty}{0}$ & กิ & $\frac{9}{0}$ & กิ & $\cong$ & $\overline{0}$ & 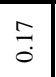 & $\stackrel{n}{0}$ & $\begin{array}{l}\overline{\mathrm{T}} \\
0\end{array}$ & $\overrightarrow{\widehat{্}}$ & \begin{tabular}{l}
\multirow{0}{0}{} \\
\end{tabular} & $\begin{array}{l}\infty \\
0\end{array}$ & $\begin{array}{l}0 \\
0\end{array}$ & $\stackrel{7}{0}$ & $\begin{array}{l}0 \\
0 \\
0\end{array}$ & $\stackrel{7}{0}$ & $\frac{m}{0}$ & $\frac{9}{0}$ & $\frac{9}{0}$ \\
\hline$\tilde{U}$ & $\frac{n}{0}$ & $\frac{n}{0}$ & \begin{tabular}{l|}
$\frac{n}{0}$ \\
\end{tabular} & $\frac{n}{0}$ & $\begin{array}{l}\frac{n}{0} \\
\end{array}$ & $\frac{\infty}{0}$ & \begin{tabular}{l|}
$\infty$ \\
0
\end{tabular} & 0 & $\stackrel{\circ}{\circ}$ & $\overline{0}$ & 7 & $\frac{m}{0}$ & $\frac{9}{0}$ & $\frac{9}{0}$ & $\frac{9}{0}$ & $\frac{7}{0}$ & \begin{tabular}{l|} 
\pm \\
0
\end{tabular} & $\frac{n}{0}$ & $\frac{n}{0}$ & $\frac{n}{0}$ & $\begin{array}{l}m \\
0\end{array}$ & $\frac{9}{0}$ & $\frac{\infty}{0}$ \\
\hline$\tilde{\mho}$ & $\stackrel{7}{0}$ & $\frac{n}{0}$ & $\frac{n}{0}$ & $\frac{7}{0}$ & $\stackrel{7}{0}$ & $\frac{\infty}{0}$ & $\frac{9}{0}$ & $\stackrel{9}{0}$ & $\stackrel{\simeq}{\circ}$ & $\mathrm{N}$ & $\frac{\infty}{0}$ & $\overline{0}$ & $\frac{9}{0}$ & $\frac{9}{0}$ & $\frac{9}{0}$ & $\stackrel{n}{0}$ & $\stackrel{\circ}{0}$ & $\dddot{7}$ & $\frac{0}{0}$ & $\exists$ & $\stackrel{ \pm}{0}$ & $\stackrel{\infty}{0}$ & $\stackrel{m}{0}$ \\
\hline
\end{tabular}


International Journal of Mathematical, Engineering and Management Sciences

Vol. 5, No. 4, 567-590, 2020

https://doi.org/10.33889/IJMEMS.2020.5.4.047

According to the results of the fuzzy DEMATEL causal diagram (see Figure 3), we state the following:

1) The Cause Group consists of Technology (C9), Product Design (C3), Organizational Structure and Management (C20), Applying Lean Practices in Management (C21), Employee Involvement (C17), Adaptation in JIT Philosophy (C13), JIT Implementation (C14), Sales Management (C12), Production Planning (C5), and Value Management (C22).

2) The Effect Group consists of Employee Cross-Functioning (C18), Total Quality Management (C23), Production Process (C7), Inventory Management (C6), Supplier Relationship Management (C1), Procurement Management (C2), Customer Relationship Management (C10), Layout Design (C4), Financial Management (C16), Cost Management (C15), Customer Satisfaction (C11), Employee Benefits (C19), and Productivity (C8).

Cause factors refer to the influencing factors. It is critical to monitor cause factors in order to attain high performance from effect factors, which can be referred to as influenced factors (Fontela and Gabus, 1976). Within this context, an adaptation of JIT Philosophy (C13) is the most important factor, because it has the most significant relationship among all factors (it has the highest $\mathrm{D}+\mathrm{R}$ value). The second and third were JIT Implementation (C14), and Production Process (C7) respectively. Technology (C9) is the most influencing factor, located at the top of the Cause Group, and Productivity (C8) is the most influenced factor, located at the bottom of the Effect Group.

Technology and product design are at the top of the cause group; therefore, the company should focus on the R \& D activities, concentrating on the Industry 4.0 from the technology aspect, and concurrent engineering on the product design aspect. As a result, the opportunities in Industry 4.0 may contribute to productivity, which is at the top of the effect group.

The third and fifth influencing factors of Cause Group are organizational structure and employee involvement. Hence, we suggest for management to choose a matrix organization structure. This may increase employee involvement with its interdisciplinary structure and may even contribute to the JIT implementation which was the second most important factor in the results.

The Lean practices in management and the JIT philosophy were the fourth and sixth influencing factors in the results of the study in which the importance of senior management arises. Therefore, the companies may benefit from the establishment of a lean council to allocate the required resources and take decisions in this strategic issue. This will eventually make a contribution to the first and second most important factors of the study, adaptation in JIT philosophy, and JIT implementation, respectively.

The first influenced factor in the Effect Group is productivity; therefore, the company should consider it as a strategic competitive advantage, and focus on the production process which was the third most important factor in our study. Therefore, the first implication is that the design phase should be based on the modularity of the products whereas the second implication is to implement cellular manufacturing to increase the productivity of the production process and the third implication is aforementioned focusing on Industry 4.0.

The second and third influenced factors of the Effect Group are, employee benefits and customer satisfaction, respectively. By using Total Quality Management principles, the management should 
institutionalize the internal and external customer concepts. In order to do this, related training and educational programs can be organized and conducted to contribute lean practices in management, employee involvement; and therefore, adaptation in JIT philosophy, and JIT implementation.

The technology factor may affect productivity. As technology supports the efficient use of resources it is crucial to improve productivity. Another aspect is the third most important factor which is the production process. The technology shows itself especially through automation in the production process which reveals that the plastics industry should transform Industry 4.0 as soon as possible. Therefore, investing in technology in the production process based on industry 4.0 will bring productivity.

The technology factor may affect customer satisfaction. The technology factor may support customer satisfaction in two ways, firstly, the improved product features and secondly, increased product and quantity variety may contribute to customer satisfaction. In order to pursue the positive effect of technology on customer satisfaction, additional features should be added through product design, which is the next cause-effect. As the next step flexibility should be improved. Especially with JIT implementation which is the second important factor, pull system may contribute to faster order fulfillment and flexibility with satisfying relatively small lot sizes.

Another outcome of the model may be that the effect of product design on productivity. As the design of the product is made simpler and suitable for modularization the productivity will be positively affected. In this way, possible problems and obstacles that may arise against productivity can be observed and even prevented. Especially concurrent engineering can be applied to facilitate the interdisciplinary teamwork within the systems approach.

There may be another effect caused by design for customer satisfaction. Generally, the design is an important issue to increase customer satisfaction with improved and enriched product features and functions. However, in the plastics industry, value-added products play an important role in the competition. Therefore, innovation is an important aspect of this case. In design and innovation activities 3D printers should be hired for faster prototyping and analyzing the product. In addition, Quality Function Deployment (QFD) can be applied, the voice of the customer can be heard and reflected the product within the capabilities of the company. Meanwhile, the second most important factor of the model, JIT implementation, is going to increase customer satisfaction by providing flexibility and shorter lead times as mentioned above.

Organizational structure and management may be revealed as a factor affecting employee benefits. The organizational structure is important for an employee for job satisfaction. One way to increase job satisfaction is related to job enrichment. Therefore, a matrix organization is suggested for these companies to facilitate interdisciplinary teamwork and job enrichment, as just we can see in concurrent engineering and in interdisciplinary design teams. The most important factor appears to be Adaptation to JIT where the matrix organization structure is strongly suggested in the transformation phase.

\section{Conclusion}

The concept of lean is founded on the principle that customer needs are to be provided at the right time, at the right place and at the right quantity. When a company adopts the lean management philosophy, it means that the aim of the company is to eliminate waste throughout the company in the process of meeting customers' demands. Currently, manufacturing processes are facing a shift 
towards lean manufacturing practices due to the lower costs, shorter processing time and more efficient processes. With this kind of transition, there is a need for companies to assess their level of leanness throughout the company. The usage of the assessment will provide the management with information to reveal both their strong and weak aspects.

This study employs a holistic approach, by integrating different dimensions of lean to create a framework which contains 8 criteria: supplier issues, manufacturing activities, marketing, just-intime, cost and financial management, workforce, management responsibility, and quality management. We also present 23 sub-criteria and 209 measurements for the use in the evaluation of the leanness of a firm.

The main three contributions of this study are, 1) to reveal the different dimensions of lean assessment, such as supplier issues, manufacturing activities, marketing, just-in-time, cost \& financial management, workforce, management responsibility, and quality management; 2) to present a new holistic leanness assessment framework within a three-level structural format as criteria, subcriteria and measures; and 3) to use fuzzy DEMATEL method in order to determine the importance level and causal relationships between the sub-criteria and consequently, to propose managerial implications which may guide managers to implement the proposed structural leanness assessment framework. Figure 1 shows the flow diagram identifying the structure of the paper. Finally, we conclude with an application of the framework in the plastics industry.

The limitation of this research is that, as with all Multi-Criteria Decision-Making (MCDM) applications, the research includes subjective judgments. The proposed leanness assessment framework may be generalized, however; the result of the implementation of the framework is industry-specific.

Further research could focus on finding the criteria weights, respective measurement weights, and an overall performance score of the company. In addition, different methods may be employed to assess the level of leanness.

\section{Conflict of Interest}

The authors confirm that there is no conflict of interest to declare for this publication.

\section{Acknowledgements}

Authors express their sincere thanks to the 18 companies operating in the plastics industry in Izmir, Turkey for pairwise comparisons.

\section{References}

Allen, J., Stewart, D., \& Robinson, C. (2001). Lean manufacturing: a plant floor guide. Society of Manufacturing Engineers. U.S.

Almomani, M.A., Abdelhadi, A., Mumani, A., Momani, A., \& Aladeemy, M. (2014). A proposed integrated model of lean assessment and analytical hierarchy process for a dynamic road map of lean implementation. The International Journal of Advanced Manufacturing Technology, 72(1-4), 161-172.

Azadeh, A., Zarrin, M., Abdollahi, M., Noury, S., \& Farahmand, S. (2015). Leanness assessment and optimization by fuzzy cognitive map and multivariate analysis. Expert Systems with Applications, 42(1516), 6050-6064. 
International Journal of Mathematical, Engineering and Management Sciences

Vol. 5, No. 4, 567-590, 2020

https://doi.org/10.33889/IJMEMS.2020.5.4.047

Azevedo, S.G., Govindan, K., Carvalho, H., \& Cruz-Machado, V. (2012). An integrated model to assess the leanness and agility of the automotive industry. Resources, Conservation and Recycling, 66, 85-94.

Bayou, M.E., \& De Korvin, A. (2008). Measuring the leanness of manufacturing systems-a case study of ford motor company and general motors. Journal of Engineering and Technology Management, 25(4), 287-304.

Behrouzi, F., \& Wong, K.Y. (2011). Lean performance evaluation of manufacturing systems: a dynamic and innovative approach. Procedia Computer Science, 3, 388-395.

Bhasin, S. (2008). Lean and performance measurement. Journal of Manufacturing Technology Management, 19(5), 670-684.

Bhasin, S. (2011). Measuring the leanness of an organisation. International Journal of Lean Six Sigma, 2(1), $55-74$.

Bhasin, S. (2012). Performance of lean in large organisations. Journal of Manufacturing Systems, 31(3), 349357.

Bhasin, S., \& Burcher, P. (2006). Lean viewed as a philosophy. Journal of Manufacturing Technology Management, 17(1), 56-72.

Biazzo, S., \& Panizzolo, R. (2000). The assessment of work organization in lean production: the relevance of the worker's perspective. Integrated Manufacturing Systems, 11(1), 6-15.

Brown, S., Blackmon, K., Cousins, P., \& Maylor, H. (2001). Operations management: policy, practice and performance improvement, Routledge.

Chan, F.T., Qi, H.J., Chan, H., Lau, H.C., \& Ip, R.W. (2003). A conceptual model of performance measurement for supply chains. Management Decision, 41(7), 635-642.

Comm, C.L., \& Mathaisel, D.F. (2000). A paradigm for benchmarking lean initiatives for quality improvement. Benchmarking: An International Journal, 7(2), 118-128.

Conner, G. (2001). Lean manufacturing for the small shop. 1st ed. Mich: Society of Manufacturing Engineers, Dearborn.

Demeter, K., \& Matyusz, Z. (2011). The impact of lean practices on inventory turnover. International Journal of Production Economics, 133(1), 154-163.

Deming, W.E. (1986). Out of the Crisis, MIT Press, Cambridge.

Devlin, S.J., Dong, H.K., \& Brown, M. (1993). Selecting a scale for measuring quality. Marketing Research, 5(3), 12-17.

Doolen, T.L., \& Hacker, M.E. (2005). A review of lean assessment in organizations: an exploratory study of lean practices by electronics manufacturers. Journal of Manufacturing Systems, 24(1), 55-67.

Emiliani, M.L. (2000). Cracking the code of business. Management Decision. 38(2), 60-79.

Feld, W.M. (2000). Lean manufacturing: tools, techniques, and how to use them. 1st ed. Alexandria, VA: St. Lucie Press.

Fontela, E., \& Gabus, A. (1976). The DEMATEL observer. DEMATEL 1976 Report. Battelle Geneva Research Center, Geneva, Switzerland.

Fullerton, R.R., \& Wempe, W.F. (2009). Lean manufacturing, non-financial performance measures, and financial performance. International Journal of Operations \& Production Management, 29(3), 214-240.

Fullerton, R.R., Kennedy, F.A., \& Widener, S.K. (2014). Lean manufacturing and firm performance: the incremental contribution of lean management accounting practices. Journal of Operations Management, 32(7-8), 414-428. 
International Journal of Mathematical, Engineering and Management Sciences

Vol. 5, No. 4, 567-590, 2020

https://doi.org/10.33889/IJMEMS.2020.5.4.047

Furlan, A., Vinelli, A., \& Dal Pont, G. (2011). Complementarity and lean manufacturing bundles: an empirical analysis. International Journal of Operations \& Production Management, 31(8), 835-850.

Gabus, A., \& Fontela, E. (1972). World problems, an invitation to further thought within the framework of DEMATEL. Battelle Geneva Research Center, Geneva, Switzerland.

Gabus, A., \& Fontela, E. (1973). Perceptions of the world problematique: Communication procedure, communicating with those bearing collective responsibility. Battelle Geneva Research Centre, Geneva, Switzerland.

González-Benito, J. (2005). A study of the effect of manufacturing proactivity on business performance. International Journal of Operations \& Production Management, 25(3), 222-241.

González-Benito, J., \& González-Benito, Ó. (2005). Environmental proactivity and business performance: an empirical analysis. Omega, 33(1), 1-15.

Goodson, R.E. (2002). Read a plant-fast. Harvard Business Review, 80(5), 105-113.

Gurumurthy, A., \& Kodali, R. (2009). Application of benchmarking for assessing the lean manufacturing implementation. Benchmarking: An International Journal, 16(2), 274-308.

Hayes, R.H., \& Wheelwright, S.C. (1984). Restoring our competitive edge: competing through manufacturing. John Wiley \& Sons, New York.

Hervani, A.A., Helms, M.M., \& Sarkis, J. (2005). Performance measurement for green supply chain management. Benchmarking: An International Journal, 12(4), 330-353.

Hines, P., \& Taylor, D. (2000). Going lean, Cardiff, UK: Lean Enterprise Research Centre Cardiff Business School.

Hopp, W.J., \& Spearman, M.L. (2004). To pull or not to pull: what is the question?. Manufacturing \& Service Operations Management, 6(2), 133-148.

Hosseini Nasab, H., Aliheidari Bioki, T., \& Khademi Zare, H. (2012). Finding a probabilistic approach to analyze lean manufacturing. Journal of Cleaner Production, 29, 73-81.

Huson, M., \& Nanda, D. (1995). The impact of just-in-time manufacturing on firm performance in the US. Journal of Operations Management, 12(3-4), 297-310.

Imai, M. (1986). Kaizen: the key to Japan's competitive success. 1st ed. McGraw-Hill, New York.

Jabbour, C.J.C., de Sousa Jabbour, A.B.L., Govindan, K., Teixeira, A.A., \& de Souza Freitas, W.R. (2013). Environmental management and operational performance in automotive companies in Brazil: the role of human resource management and lean manufacturing. Journal of Cleaner Production, 47, 129-140.

Karaca, M.E. (2011). Plastik ve Kauçuk Ürünleri İmalatı Available at: http://www.kalkinma.com.tr/data/file/raporlar/ESA/ga/2012-GA/esamkitap/pdf/plastik.pdf

Kennedy, F.A., \& Widener, S.K. (2008). A control framework: Insights from evidence on lean accounting. Management Accounting Research, 19(4), 301-323.

Liker, J.K. (1998). Becoming lean: inside stories of US manufacturers. Productivity Press, Portland, OR.

Liker, J.K. (2004). The Toyota way. McGraw-Hill, New York.

Narasimhan, R., Swink, M., \& Kim, S.W. (2006). Disentangling leanness and agility: an empirical investigation. Journal of Operations Management, 24(5), 440-457.

Ohno, T. (1988). The Toyota production system: beyond large scale production. Portland, OR.

Opricovic, S., \& Tzeng, G.H. (2003). Defuzzification within a multicriteria decision model. International Journal of Uncertainty, Fuzziness and Knowledge-Based Systems, 11(05), 635-652. 
International Journal of Mathematical, Engineering and Management Sciences

Vol. 5, No. 4, 567-590, 2020

https://doi.org/10.33889/IJMEMS.2020.5.4.047

Pakdil, F., \& Leonard, K.M. (2014). Criteria for a lean organisation: development of a lean assessment tool. International Journal of Production Research, 52(15), 4587-4607.

Pettersen, J. (2009). Defining lean production: some conceptual and practical issues. The TQM Journal, 21(2), 127-142.

Piercy, N.F., \& Morgan, N.A. (1997). The impact of lean thinking and the lean enterprise on marketing: threat or synergy? Journal of Marketing Management, 13(7), 679-693.

Saurin, T.A., Marodin, G.A., \& Ribeiro, J.L.D. (2011). A framework for assessing the use of lean production practices in manufacturing cells. International Journal of Production Research, 49(11), 3211-3230.

Schonberger, R. (1987). World class manufacturing casebook: implementing JIT and TQC. 1st ed. The Free Press, New York.

Searcy, D.L. (2009). Developing a lean performance score: here's a way to track the progress of your lean journey. Strategic Finance, 91(3), 34-40.

Shah, R., \& Ward, P.T. (2003). Lean manufacturing: context, practice bundles, and performance. Journal of Operations Management, 21(2), 129-149.

Shah, R., \& Ward, P.T. (2007). Defining and developing measures of lean production. Journal of Operations Management, 25(4), 785-805.

Sharma, M.K., \& Bhagwat, R. (2007). An integrated BSC-AHP approach for supply chain management evaluation. Measuring Business Excellence, 11(3), 57-68.

Shaw, M.E. (1970). Theories of social psychology. McGraw-Hill, New York.

Singh, B., Garg, S.K., \& Sharma, S.K. (2010). Development of index for measuring leanness: study of an Indian auto component industry. Measuring Business Excellence, 14(2), 46-53.

Soriano-Meier, H., \& Forrester, P.L. (2002). A model for evaluating the degree of leanness of manufacturing firms. Integrated Manufacturing Systems, 13(2), 104-109.

Taj, S. (2005). Applying lean assessment tools in Chinese hi-tech industries. Management Decision, 43(4), 628-643.

Vinodh, S., \& Chintha, S.K. (2011). Leanness assessment using multi-grade fuzzy approach. International Journal of Production Research, 49(2), 431-445.

Wan, H.D., \& Frank Chen, F. (2008). A leanness measure of manufacturing systems for quantifying impacts of lean initiatives. International Journal of Production Research, 46(23), 6567-6584.

Womack, J.P., \& Jones, D.T. (1996). Lean thinking: banish waste and create wealth in your corporation, Simon \& Schuster, New York.

Womack, J.P., \& Jones, D.T. (2003). Lean thinking: banish waste and create wealth in your corporation, Free Press, New York.

Wong, W.P., Ignatius, J., \& Soh, K.L. (2014). What is the leanness level of your organisation in lean transformation implementation? An integrated lean index using ANP approach. Production Planning \& Control, 25(4), 273-287.

Wu, W.W., \& Lee, Y.T. (2007). Developing global managers' competencies using the fuzzy DEMATEL method. Expert Systems with Applications, 32(2), 499-507.

Wu, Y.C. (2003). Lean manufacturing: a perspective of lean suppliers. International Journal of Operations \& Production Management, 23(11), 1349-1376. 